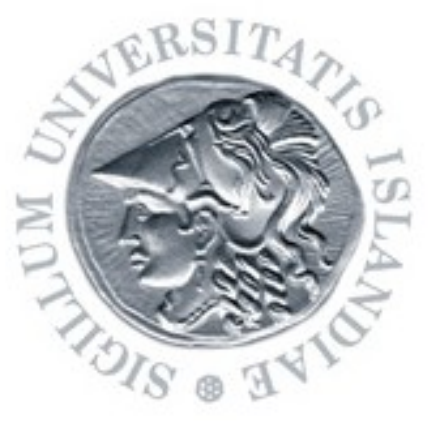

University of Iceland

Faculty of Nursing

\title{
Technological dependency - The experience of using home ventilators and long-term oxygen therapy: Patients' and families' perspective
}

Porbjörg Sóley Ingadóttir

Supervised by Dr. Helga Jónsdóttir, Professor, Faculty of Nursing, University of Iceland

Thesis submitted for a Master of Science degree (30 credits) October 2004 
MS review committee

Dr. Helga Jónsdóttir, Professor, Faculty of Nursing, University of Iceland Salvör Nordal, Director, Institude of Ethics, University of Iceland Susan Patricia Dunning MD, lung physician

CPorbjörg Sóley Ingadóttir, 2004

Printed in Iceland by Háskólafjölritun ehf., Reykjavík 2004 


\begin{abstract}
Abtstract
This study describes patients' and families' experience of long-term home treatment with non-invasive ventilation during sleep with or without additional oxygen therapy. The treatment is based on positive airway pressure delivered to the patient via nasal mask or a combined nasal/mouth mask. Various chronic diseases can lead to sleep related breathing disorders, which present with sleep apnea and or hypoventilation during sleep. Without the treatment the patients may suffer from serious consequences of insufficient gas exchange. Considering the potential burden placed on people undertaking this treatment it is necessary to obtain peoples' experience of this treatment in order to prevent unnecessary problems. The main research question is: What is patients' and families' experience of technical breathing assistance during sleep?

Technology and caring are prominent concepts in the literature on technological dependency. Technology in health care has been defined as any technique and technology used for diagnosing, treating and controlling peoples' health. Controversy exists as to how technology and caring may be reconciled in nursing practice.

The methodological approach was interpretive phenomenology and thematic and narrative analysis. The participants were chosen from a group of about 100 Icelandic patients using home ventilation technology. The sample was purposive and interviews were taken with 6 patients age 45-70 and 5 spouses and one daugther. Data was collected with two 1 hour-long deep interviews with each pair of participants

The main narratives that emerged from the data were: 1 . Mixed blessing: Life saving treatment - meaningless exertion. 2. Being in the hands of professionals compassion and understanding as central. 3. Listening to the body. 4. Wanting to be seen as healthy. 5. Powerful technology. 6. The treatment involves routine work and effort.

It is concluded that being dependent on technical breathing assistance during sleep was a major life event for participants. The treatment was experienced as constraining and intrusive in life despite successful outcome. Not everybody found the treatment helpful and it provoked questions on purpose. This indicates that the way the technique is introduced and consequently put into action is crucial. Professionals need, therefore, to pay a close attention to how they practice and put caring concern and respect for unique needs of individuals in forefront.
\end{abstract}

Keywords: Non-invasive ventilation, Sleep disordered breathing, Technological dependency, Qualitative methodology. 


\section{Útdráttur}

Tilgangur rannsóknarinnar er að lýsa reynslu sjúklinga og fjölskyldna peirra af tæknilegri aðstoð við öndun í svefni með eða án súrefnisnotkunar. Aðstoðin byggist á blásturstæki sem myndar jákvæðan loftprýsting og veitt er í vit sjúklingsins gegnum öndunargrímu sem sofið er með. Peir einstaklingar sem parfnast pessa búnaðar eru með ýmsa langvinna sjúkdóma, sem valda truflun á öndun og minnkaðri öndunargetu í svefni. Án meðferðarinnar geta sjúklingarnir pjáðst af alvarlegum afleiðingum truflaðra loftskipta. Miklar tækniframfarir hafa átt sér stað í próun meðferðarinnar og er sífellt fleiri sjúklingum gefinn kostur á henni. Í ljósi pess er nauðsynlegt að skoða hver reynsla sjúklinganna af meðferðinni er og koma með bví í veg fyrir að hún valdi óparfa erfiðleikum og par með nýjum heilsufarsvandamálum. Meginrannsóknarspurningin er pví: Hver er reynsla sjúklinga og fjölskyldna peirra af tæknilegri meðferð til öndunaraðstoðar í svefni.

Degar reynsla fólks af tæknilegri meðferð er skoðuð eru hugtökin tækni og umhyggja áberandi. Tækni í heilbrigðiskerfinu er venjulega skilgreind sem hvers konar tæki og tækni sem notuð er til sjúkdómsgreiningar og meðferðar. Fagfólk greinir á um hvernig best megi sampætta petta tvennt. Sýnt hefur verið fram á að sjúklingar geta átt í erfiðleikum með að piggja og sætta sig við meðferð vegna áhrifa á félagslega og andlega líðan, pó sýnt sé að hún beri tilætlaðan árangur.

Aðferðafræði: Rannsóknin var eigindleg og byggir á túlkandi fyrirbærafræði og frásögugreiningu. Pátttakendur voru valdir úr hópi rúmlega 100 íslenskra sjúklinga sem nota ofangreindan búnað, búa heima og voru á aldrinum 40-70 ára. Úrtakið var pægindavalið og samanstóð af sex sjúklingum, ásamt fimm mökum og einni dóttur. Gagnasöfnun var framkvæmd með tveim um pað bil 1 klst. löngum opnum viðtölum við hvert par pátttakenda. Gagnagreining fólst í frásögugreiningu.

Niðurstöður: Eftirfarandi frásögur komu fram: 1. Fjölbreytileg upplifun á áhrifum meðferðar: Algjör lífsnauðsyn - tilgangslaust erfiði. 2. Að vera í höndum fagfólks - mikilvægi samkenndar og skilnings. 3. Að hlusta á skilaboð líkamans. 4. Аð vera heilbrigður í sjúklingshlutverkinu. 5. Máttur tækninnar - erfitt að hafna meðferð. 6. Fyrirhöfn í daglegu lífi - að hleypa í sig kjarki til að fara í vélina.

Ályktanir: Að vera háđur öndunaraðstoð í svefni var verulegt inngrip í líf pátttakenda. Meðferðin var séð sem pvingandi inngrip í líf peirra prátt fyrir góðan árangur. Meðferðin var ekki hjálpleg fyrir alla og kallaði pað á spurningar um tilgang. Gagnsemin var breytileg og mátti rekja til ýmissa pátta, einkum alvarleika heilsufarsvandans og almenns heilsufars peirra. Umhyggjusöm samskipti af hálfu heilbrigðisstarfsmanna og virðing fyrir sérstökum pörfum skjólstæðinga einkum við upphaf meðferðar, skiptu verulegu máli.

Lykilorð: Meðferð með heimaöndunarvél, Langtíma súrefnismeðferð, Svefnháðar öndunartruflanir, Tækni og umhyggja í hjúkrun, Að vera háður tækni, Eigindleg aðferðafræði. 


\section{Acknowledgements}

This thesis consists of a study conducted as a part of a master program at the Faculty of Nursing, University of Iceland. The study was possible because I was supported and inspired by many people during the research process. First I would like to thank the participants in the study for sharing with me their experience. I want to thank Alda Gunnarsdóttir head nurse in the lung department at the University Hospital of Iceland for contacting the participants and I also thank her for very good support during the course of my studies. Special thanks to the nurses Bryndís Halldórsdóttir, Stella Hrafnkelsdóttir, Guðlaug Steinsdóttir and Rósa Karlsdóttir, the nursing assistants Jóhanna Júlíusdóttir and Oddný Fjóla Lárusdóttir, the technician Elsa Eiríksdóttir, and the lung physicians Pórarinn Gíslason and Dóra Lúðvíksdóttir for proofreading the results and for their helpful suggsetions. I also want to thank other colleagues at the lung department for their support. Special thanks to my friend and former colleague Jóna Valgerður Höskuldsdóttir and to the physician Guðbrandur Kjartansson for support and inspiration throughout the years. I thank the former director of nursing at the University Hospital, Bjarney Tryggvadóttir and the present director Guðlaug Rakel Guðjónsdóttir for giving me the opportunity to take a particial study leave.

My husband Nikulás Úlfar Másson and my four children, my parents and my inlaws for all their help and endurance.

I thank my review committee Salvör Nordal and Susan Dunning for good collaboration and helpful suggestions.

I thank professor Helga Jónsdóttir for giving me the opportunity to work with her and for her exceptional guidance and inspiration.

The Icelandic Centre for Research; The Icelandic Nursing Association; and the University Hospital of Iceland provided funding for the study and I thank for their support. 


\section{Contents}

Abtstract iii

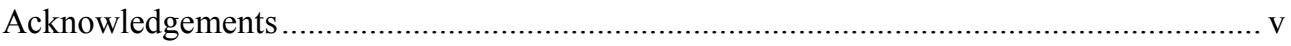

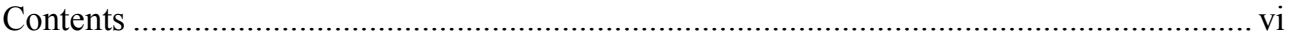

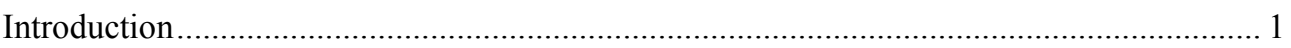

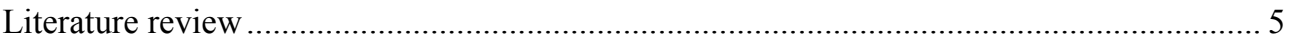

Diseases and Treatment Possibilities .......................................................... 5

Diagnosis of Sleep Related Breathing Disorders......................................5

Main Causes for Sleep Related Breathing Disorders.................................6

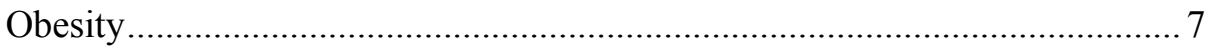

Congestive Heart Failure ............................................................... 8

Neuro-Muscular and Chest Wall Disorders............................................... 9

Chronic Obstructive Pulmonary Disease .................................................. 9

Consequences of Untreated Breathing Disorders During Sleep ................... 10

Technical Treatment in the form of Non-invasive Ventilation...................... 10

History of Non-invasive Ventilatory Treatment in Iceland ......................... 13

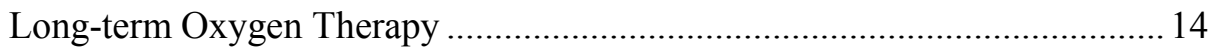

Technology and Caring in Nursing ..................................................... 15

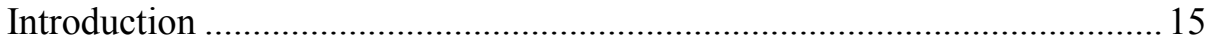

Main Approaches to Technology and Caring in Nursing ........................... 16

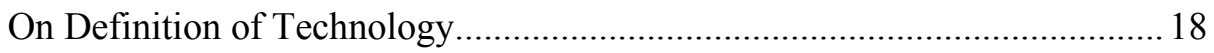

Technology and Caring in Nursing..................................................... 20

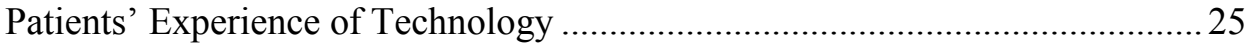

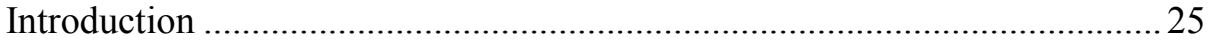

The Lived Experience of Disease ....................................................... 26

Theoretical Frameworks of Technological Dependency ............................2 27 
Studies of Technological Dependency of Persons Using Ventilation

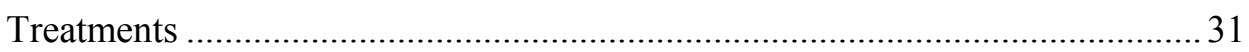

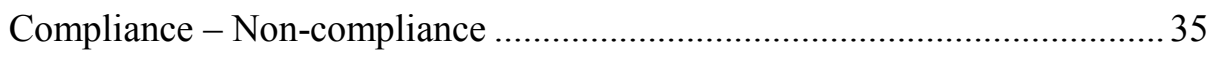

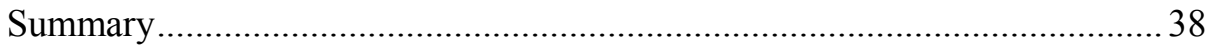

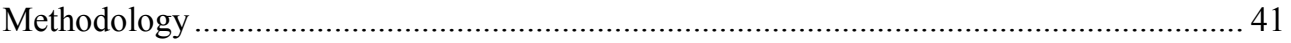

Interpretive Phenomenology .......................................................................... 41

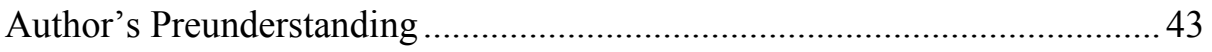

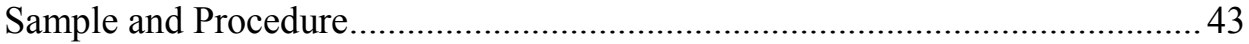

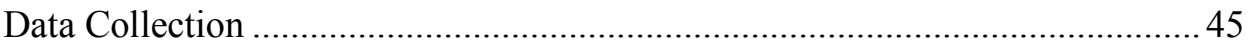

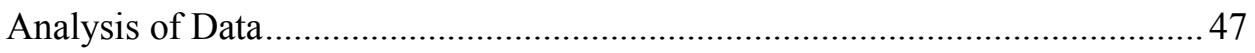

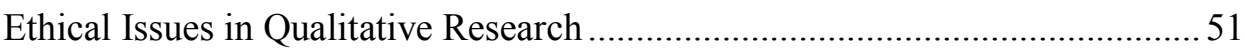

Rigor in Qualitative Research ......................................................................5 52

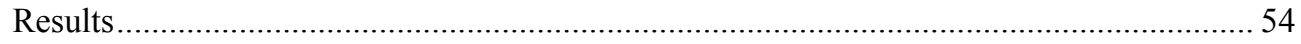

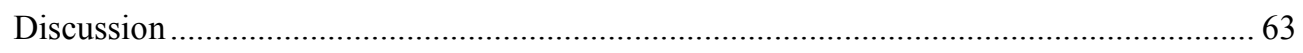

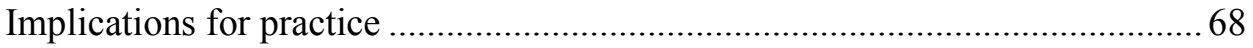

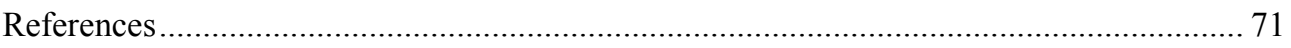

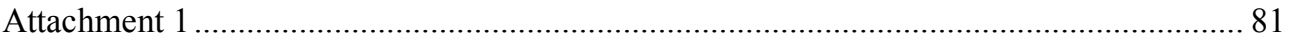

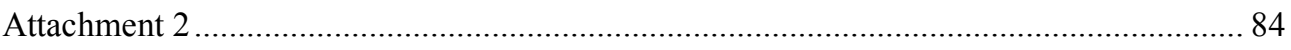

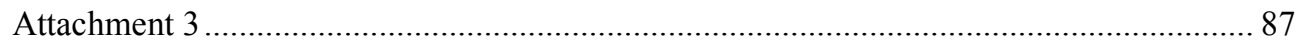




\section{Introduction}

The purpose of this study is to describe the experience of being dependent on technology in the form of home treatment with non-invasive ventilation with or without long-term oxygen. It was in 1987 that facilities for sleep research were available and monitoring of sleep related breathing disorders started in Iceland. Subsequently treatment with non-invasive ventilators was initiated to aid ventilation during sleep. From the beginning monitoring and treating sleep related breathing disorders has taken place at a sleep clinic related to the pulmonary unit at the National University Hospital in Reykjavík. In the past few years there has been a rapid progress in the monitoring technology, enabling more detailed studies and consequently ensuring a better choice of relevant treatment. Concurrently there has been a rapid increase in patient's referral to the sleep laboratory. This is due to increased knowledge among health professionals and the general public about the high prevalence of sleep related breathing disorders occurring in certain patient population.

The most prevalent diseases associated with impaired breathing during sleep are, congestive heart failure, neuromuscular diseases and respiratory failure (Claman, Piper, Sanders, Stiller \& Votteri, 1996). Diagnosis of disturbed breathing during sleep occurs frequently in an acute situation, when patients are admitted to hospital due to respiratory failure or progression of an underlying disease. The treatment most commonly used in this situation is non-invasive ventilation.

The term non-invasive ventilation refers to ventilation treatment without intubation. The technique improves gas exchange by blowing air with positive pressure through a nose mask or a combined nose and mouth mask, thus preventing alveoli collapse and supplementing the patient's ventilatory efforts. This treatment is normally referred to as BiPAP treatment, "Bilevel positive airway pressure", which as the name implies delivers air into the alveoli with two levels of positive pressure (Perkins \& Shortall, 2000). 
Increased use of non-invasive ventilation calls for careful exploration of the consequences for the persons who undertake the treatment and their spouses. Are they only beneficial or is it possible that there might exist negative consequences of the treatment? The façade of fancy technological devices has been prominent. It is, however, of the greatest importance to uncover the human experience of undertaking this treatment and being dependent on this technology.

Several studies exist concerning living with technology in various forms, but very few were found regarding non-invasive ventilation and oxygen therapy. No studies on these issues have been performed in Iceland. Related literature, revealing the experience of living with technology on a long-term basis reveals a dichotomous approach towards the treatment. It appears to be vital and wanted at the same time as it is cumbersome to live with (Beery, Sommers \& Hall, 2002; Burke, 1996; Cooper \& Powell, 1998; Fitch \& Ross, 1998; Gelinas, O’Conner \& Miller, 1998; Lindahl, Sandman \& Rasmussen 2003).

Technology in nursing has been of interest of several nursing scholars for several years particularly in relation to the concept of caring (Barnard, 1997; Gadow, 1984; Locsin, 1995; McConnell, 1998; Ray, 1987). The main questions that have been raised are if and how these two concepts relate to each other and how it is possible to tailor health care to fit patients and their relatives in the best possible way in harmony with their life (Sandelowski, 1993). It is important to consider these questions in relation to treatment with breathing devices as such treatment can have extensive effects on peoples' daily life (Fitch \& Ross, 1998; Gelinas, O'Conner \& Miller, 1998; Lindahl, Sandman \& Rasmussen 2003). Caring communications with people about the use of technology with a holistic view of the persons' situations and circumstances in life are important (Sandelowski, 1993).

The patients who the research is directed towards are chronically ill patients, having various diseases that result in hypoventilation and other disturbances of breathing during sleep and who have been prescribed non-invasive ventilation technology at home. The reason for choosing this subject is the author's perceived need to gain 
increased knowledge on the experience of this group of patients, which has rapidly increased in number during the last two years (Halldórsdóttir, Ingadóttir \& Gíslason, 2003) in order to be able to deliver optimal health care. When a patient has been diagnosed and it is known that he/she would benefit from ventilator support, it is very important for the patient to meet supportive and guiding attitude from the professionals. The author's opinion is that, to obtain knowledge by studying the patients' experience, enhances quality of care that is delivered to the patients. The majority of patients receiving this treatment are middle age and older, although there are few younger ones. This study focuses on the experience of different age groups in order to get a broad perspective on the issue. The author's belief is that the benefits will be, both to obtain knowledge and to give attention to this group of patients by highlighting their needs through illuminating their experience.

In order to study human experience in relation to the environment, culture and values, one has to search for a theory that captures these aspects. After studying interpretive phenomenology, it appeared to be the most appropriate method to use for this purpose. Tape-recorded interviews were conducted, with 6 patients, 40-70 years of age and their spouse or a family member. The interviews were written verbatim, and analysed with thematic and narrative analysis (Benner, 1994; Polkinghorne, 1988, 1995).

The author expects that this study may become a significant contribution for the discipline of nursing. This study will increase understanding of how technology impacts people's lives in these particular circumstances and help with understanding the restrictions this may have. This knowledge may in turn enhance nurse's understanding and capacity to help the patients and their relatives to make informed decisions about how to undertake non-invasive ventilation treatment. By knowing what is of most importance to the people involved in these circumstances, it helps with constructing and tailoring the best possible care to patients and their families. 
The research question is: What is the experience of being dependent on technology in the form of non-invasive ventilator assistance, from the patients' and families' point of view? 


\section{Literature review}

In this chapter chronic diseases causing sleep related breathing disorders and the consequences that untreated condition can have on people's health, will be reviewed. The application of a common treatment for these conditions, pressure-controlled ventilators with the application of non-invasive methods, will be explained along with long-term oxygen therapy, which is also frequently given as a supplemental treatment. The handling of technology in the health care will be explored in relation to caring in nursing. Peoples' experience of various long-term technological treatments will be described along with the ethical stance following patients' abilities to undertake treatment.

Diseases and Treatment Possibilities

\section{Diagnosis of Sleep Related Breathing Disorders}

Certain diseases can lead to disordered breathing during sleep. The diagnosis of breathing disturbances is performed in a sleep laboratory with the following measurements: Arterial oxygen saturation by finger pulse oximetry; thoracoabdominal movements by electric bands placed over the thorax and abdomen; oronasal flow by thermistor; body position and heart rate variations (Golpe, Jiménez \& Carpizo, 2002) and transcutaneous $\mathrm{PCO}_{2}$ is measured via skin electrode (Guilleminault Philip \& Robinson, 1998).

Disordered breathing can be broken down into 3 areas: Central sleep apnea (CSA), Obstructive sleep apnea (OSA) and Sleep related hypoventilation. Central sleep apnea is defined as absence of airflow accompanied by a lack of respiratory effort. Obstructive sleep apnea is characterized by periodic apnea and asphyxia from upper airway obstruction or collapse in the pharynx, that continoues despite continoued respiratory effort. Hypopneas refer to narrowing of the upper airway and can be either central or obstructive in ethiology, associated with or without respiratory effort. It is 
referred to as mixed apneas if both central and obstructive components are persistent (Guilleminault, et al., 1998). The Spanish Society of Pulmonology and Thoracic Surgery has defined apnea as a complete cessation of airflow lasting $>10$ seconds and hypopnea as a disernable reduction in respiratory airflow lasting $>10$ seconds accompained by a decrease of $>4 \%$ in oxygen saturation and/or an arousal from sleep (Golpe et al., 2002). Hypoventilation is defined as presence of $\mathrm{CO}_{2}$ retention for a minumum of five minutes, without the presence of apneas as stated above (Guilleminault, et al., 1998). Perkins \& Shortall (2000) explain the physiological consequences of hypoventilation in the way that the respiratory muscles work harder to meet the need for oxygen, they get tired and become less efficient. That in turn causes oxygen pressure in the blood to drop and the carbon dioxide level to increase (hypercapnea) and consequently this condition leads to acidosis, which will further impair respiratory muscle activity. Hypoventialtion with hypercapnea is said to be the most significant of the sleep induced breathing disorders, indicating a critical imbalance between ventilatory demand and capacity, thus being a life threatening condition (Ragette, Mellies, Schwake, Voit \& Teschler, 2002). The most common symptoms following sleep disordered breathing are chronic fatigue, poor sleep quality, excessive daytime sleepiness, observed apneas and morning headaches (Dixon, Schachter \& O’Brien, 2003).

\section{Main Causes for Sleep Related Breathing Disorders}

It is becoming clear that disordered breathing during sleep are a significant problem in the heart failure population. Studies suggest that both central and obstructive sleep apnea may have significant advers effects on outcomes in heart failure patients and contribute to heart failure symptoms including fatigue. Central sleep apnea is usually secondary to congestive heart failure. It is concidered to be a marker of the severity of heart failure, since mortality is increased in this group (Somers, 2002).

Diseases that can lead to hypoventilation during sleep are: Neuromuscular diseases, abnormalities of the chest wall, chronic obstructive pulmonary disease, diaphragmatic 
dysfunction, and/or disorders of ventilator control. Alveolar hypoventilation may also be associated with cor pulmonale, nocturnal arrhythmias, morning headaches, impaired cognitive function, and reduced daytime vigilance (Claman, et al., 1996).

In the following sections will be described the main conditions associated with disordered breathing during sleep requiring non-invasive ventilation. They are: Obesity, congestive heart failure, neuro-muscular and chest wall disorders and chronic obstructive pulmonary disease.

\section{Obesity}

Obesity can impair the function of the respiratory system and lead to cardiovascular and pulmonary diseases and thus being a major scource of morbidity and mortality (Berger, et al., 2001). Burwell and colleagues described the obesity hypoventilation syndrome approximately 45 years ago in patients with morbid obesity, hypersomnolence, plethora and oedema, under the term 'Pickwickian syndrome' (Berger et al., 2001). The 'Pickwickian syndrome' entails two primary breathing disorders, which can affect patients alone or in combination: sleep apnea syndrome (SAS) and obesity hypoventilation syndrome (OHS), but is generally referred to as Pickwickian syndrome (Sugerman, et al., 1992). The American Academy of Sleep Medicine termed this syndrome 'the sleep hypoventilation syndrome' and in many of these patients obstructive sleep apnea and hypoapnea is present (Berger et al., 2001). A definate answer has not been given so far why some obese individuals develop alveolar hypoventilation and others do not, but some theories have been put forward in that respect (Jokic, et al., 2000). The first theory described by Sharp et al (Jokic et al., 2000) states that the excessive mechanical load on the respiratory muscles caused by the obesity leads to hypoventilation. This theory is supported by the fact that a substantial weight loss in these patients leads to marked improvement in their clinical condition (Sugerman et al., 1992; Thomas, Owen, Hulands, \& Milledge, 1989). This theory has been rejected by Bedell, Wilson \& Seebohm (Jokic et al., 2000), who showed that a poor correlation has been found between the degree of obesity and the 
extent of hypoventilation, particularly that most of the very obese patients do not develop hypoventilation. The second theory proposes that alveolar hypoventilation is a consequence of blunted ventilatory drive (Carrol as stated in Jokic et al., 2000). Although many studies support this notion it has been difficult to discern from these studies whether this is primary or secundary to chronic hypoxia and hypercapnia (Rochester \& Enson, as stated in Jokic et al., 2000). In a study by Jokic et al. (2000) sixteen first-degree relatives of seven patients suffering from obesity hypoventilation syndrome OHS (mean age 40 years, BMI of 30 and without severe OSA), were compared with sixteen matching subjects in age and BMI without OSA and OHS. The results showed no evidence of impaired ventilatory chemoresponsiveness in firstdegree relatives compared with the matching subjects.

\section{Congestive Heart Failure}

Approximately 40 to $50 \%$ of stable patients with congestive heart failure (CHF) suffer from either obstructive sleep apnea or Cheyne-Stokes respiration with central sleep apnea (Tkáćová, Štubňa \& Tomori, 2002). In both types of sleep apnea are several contributing mechanisms causing significant stresses on the heart. These include hypoxemia, reductions in intrathoracic pressure, rises in systemic arterial pressure, increases in left ventricular afterload and arousals from sleep, worsening the sleep arcitecture. Consequently this leads to syphathetic activation and parasymphathetic withdrawal thus contributing to the progression of heart failure and may adversely affect its prognosis. Therefore, an early diagnosis and specific treatment of sleep disturbed breathing in patients with CHF is highly warranted. The Sleep Heart Study showed that OSA increases the risk of CHF an odds ratio of 2,4 (Harding, 2000). A study by Sin, Logan, Fitzgerald, Liu \& Bradley (2000) show that the presence of CSA in heart failure patients is a marker for earlier mortality. 


\section{Neuro-Muscular and Chest Wall Disorders}

Sleep disordered breathing is common in patients suffering from neuromuscular diseases and respiratory muscle weakness. The primary mechanism includes reduction in alveolar ventilation, blunted arousal threshold and decreased activity in respiratory muscles. In addition to this there may be decreased muscle tone in the upper airway. Diaphragm weakness can further reduce breathing especially during REM sleep, which is the time of maximal muscle hypotonia (Ragette et al., 2002). The main types of progressive neuromuscular diseases causing disturbed breathing during sleep are Motor neuron disease (MND), which is characterised by progressive degeneration of certain types of nerve cells (Skelton, 1996), Muscular dystrophy with the most common type Duchenne muscular dystrophy (DMD), which is characterized by wasting of muscles with accompanying weakness and deformity in boys (Hammond \& McCann, 2003), myotonic dystrophy characterized by muscle weakness and myotonia which is a failure of the muscles to relax (Nugent, Smith \& Shneerson, 2002). Patients with chestwall deformities due to post polio syndrome, ideopatic kyphoscoliosis or patients who have had thoracoplastic due to TBC, have altered mechanics of breathing leading to hypoventilation (Kjartansson et al., 2001).

\section{Chronic Obstructive Pulmonary Disease}

Patients with COPD may be prone to problems concerning disturbed breathing during sleep. Sleep related hypoxia and hypercapnia are well recognized in COPD and are most pronounced during REM sleep. Some authors recommend a trial of noninvasive ventilation in COPD with gas exchange abnormalities related to COPD. However sleep screening are usually only indicated in patients with COPD when there is a possibility of sleep apnea and a combination of heart disease (McNicholas, 2000). 


\section{Consequences of Untreated Breathing Disorders During Sleep}

It has become clear that breathing disorders during sleep can play an important role in acute and chronic cardiovascular conditions. Both obstructive and central apneas and hypoventilation with hypoxia and hypercapnia are associated with increases in sympathetic activity, which predisposes to hypertention and heart failure (Somers, 2002). Sleep disordered breathing may predispose individuals to metabolic abnormalities which is independent of obesity and related to the severity of oxygen desaturation (Punjabi, et al., 2002). A clinical based study by Vgontzas et al., as described by Punjabi, et al. (2002) found that patients with sleep-disordered breathing have significantly higher fasting glucose and insulin levels compared with a group of weight-matched control subjects. It is maintained that the major implication of these findings is that glucose intolerance and insulin resistance may be intermediate in the causal pathway to increased morbitidy and mortality (Punjabi, et al., 2002). Sleep disordered breathing is known to cause pulmonary hypertension and arrhythmias and has been shown to increase risk of stroke and myocardial infarction (Tkáćová, et al., 2002).

In addition to the impact on the patient's health, this condition can cause a significant deterioration in productivity and quality of life (Dellborg, et al., 2002; Flemons \& Tsai, 1997). Sleep apneas can cause excessive daytime sleepiness, reduced alertness and imparied concentration, which have been shown to increase the risk of motor vehicle collisions if untreated. This rate decreases to normal once patients are treated with CPAP (George, 2001).

\section{Technical Treatment in the form of Non-invasive Ventilation}

The term non-invasive ventilation refers to ventilation treatment without intubation. The technique improves gas exchange by blowing air with positive pressure through a nose mask, a combined nose and mouth mask or a tracheostomy, to keep the alveoli open. This treatment is normally refered to as BiPAP treatment, 
"Bilevel positive airway pressure", which as the name implies delivers air into the alveoli with two levels of positive pressure. The device cycles between a predetermined inspiratory-pressure, maintained during each inhalation - inspiratory positive airway pressure (IPAP) phase and a much lower preset positive pressure during exhalation - expiratory positive airway pressure (EPAP) phase. The initiation of each breath is either from the patient or the machine itself, which is programmed with a certain number of breaths per minute as a backup. That ensures that the patient receives a set number of breaths per minute if he/she should become apnoeic (Perkins $\&$ Shortall, 2000). If non-invasive ventilation with acceptible pressure settings does not increase oxygen saturation over $90 \%$ or greater, then the patient also receives supplemental oxygen (Claman et al., 1996).

Another form of positive pressure treatment is continous positive airway pressure (CPAP), delivering continous positive airway pressure both in inhalation and exhalation. This treatment is only delivered through a nose or a combined nose and mouth mask. CPAP is the most common treatment for obstructive sleep apnea, preventing the collapse of the upper airway during sleep. CPAP can also benefit patients with cardiogenic pulmonary oedema, as an additional treatment by increasing intrathoracic pressure and thus reduce both cardiac preload and afterload, lowering heart rate and systolic blood pressure, augmenting stroke volume, improving ejection fraction and delay further fluid saturation in the lungs (Perkins \& Shortall, 2000). However, because the airway pressure is the same for both inhalation and exhalation, this is not considered non-invasive ventilation and thus is not addressed in the thesis.

A prospective study by Guilliminault, et al. (1998) was performed on 20 patients with progressive neuromuscular disease on treatment with non-invasive ventilation in order to assess the results of the treatment. Variables such as oxygen saturation, carbondioxin levels, sleepiness and latency to sleep onset during the day were mesured. Sleepiness was measured with 'Epworth sleepiness scale' (ESS), which is an 8 -item scale, measuring daytime sleepiness, where score above 10 indicate abnormal sleepiness (Johns, 1991). Latency to a sleep onset during the day is measured with 
polysomnographic study followed by a multiple sleep latency test (MSLT). MLST is a daytime test performed by asking the patient to take a nap with two hour interval where latency to sleep onset and possible appearance of REM (rapid eye movement). The results on one year follow up compared to pre treatment showed mean $\mathrm{SaO} 2$ increase from 83.1 to 92.6, $\mathrm{CO} 2$ decreased from 43.5 to 41.6, ESS scores decreased from 14.2 to 7.8 and MSLT increased from 8.1 to 12.1. These results revealed that BiPAP can be used successfully to treat sleep disordered breathing associated with neuromuscular disease. Three of the 20 patients needed low flow oxygen connected to the mask (Guilliminault, et al., 1998).

Berger, et al. (2001) identified the spectrum of respiratory disturbances during sleep in patients with obesity hypoventilation syndrome and examined the response of hypercapnea to treatment of the specific ventilatory sleep disturbances in a retrospective study $(\mathrm{N}=23)$. All participants had chronic awake hypercapnia (mean $[ \pm$ $\mathrm{SD}] \mathrm{PaCO}_{2}, 55 \pm 6 \mathrm{~mm} \mathrm{Hg}$ ). Eleven of the twenty-three patients demonstrated with obstructive sleep apnea alone and eight of them were treated with CPAP and three with tracheostomy due to intolerance of the mask. Twelve of the patients had sleep related central sleep hypoventilation in addition to a variable number of obstructive apnea events and did not hold up oxygen saturation on CPAP so the treatment needed to be changed to nocturnal ventilation, BiPAP. The expiratory airway pressure was set high enough to overcome the airway obstruction and the inspiratory airway pressure was increased until oxygen saturation was above $90 \%$. In three of the patients in the ventilatory group the increase in the inspiratory pressure was not enough to hold up oxygen saturation and oxygen was required to be added to the ventilatory circuit. The treatment resulted in correction of the chronic hypercapnia in all socalled compliant patients, according to patients self report of compliance $(\mathrm{N}=15)$ (compliant patients: pretreatment, $57 \pm 6 \mathrm{~mm} \mathrm{Hg}$ vs post treatment, $41 \pm 4 \mathrm{~mm} \mathrm{Hg}[\mathrm{p}<0.001]$; noncompliant patients: pretreatment, $52 \pm 6 \mathrm{~mm} \mathrm{Hg}$ vs post treatment, $51 \pm 3 \mathrm{~mm} \mathrm{Hg}$; [difference not significant]). 
BiPAP treatment with low-pressure settings has been shown to have improving effects on chronic congestive heart failure (CHF), with systolic dysfunction. This is reported in a non-randomised, prospective study performed by Acosta, et al. (2000) on 14 CHF patients with severe systolic dysfunction. BiPAP treatment was shown to enhance left ventricular performance by decreasing the after load, augmenting the contractility and improving the preload. Data also suggests CPAP as optimal treatment reducing mortality by $50 \%$ (Sin et al., 2000).

Non-invasive ventilation is not appropriate treatment for every patient needing ventilator support. It is contraindicated for patients who have suffered respiratory arrest, serious arrhythmias, head or facial trauma, hemodynamically unstable, excessive secretions or are incapable of cooperating with the therapy (Bachan and Hyzy as stated in Perkins \& Shortall, 2000).

\section{History of Non-invasive Ventilatory Treatment in Iceland}

Non-invasive ventilator treatment (BiPAP) has been available in Iceland since 1987. Analyzing the population of Iceland, a study based on records from all patients in Iceland using non-invasive ventilators (BiPAP) at home was reviewed. A total of 54 patients used non-invasive ventilation at home in the year 1999, 33 males and 21 females. This means that home ventilator users were about 20/100.000 inhabitats which is about the same as in Scandinavia. The mean age for the group was 61 years. The mean treatment time was 3.5 years. Most common reason for treatment was decreased respiratory muscle function. In 11 patients this was secondary to muscle- or neurological diseases, in 9 TBC sequelae and in 6 post polio or idiopathic kyphoscoliosis. In addition there were 21 patients who had a combination of chronic obstructive pulmonary disease and sleep-related breathing disorders. Cheyne-Stoke breathing secondary to congestive heart failure was the reason for home ventilatory treatment in 7 individuals. The patients suffering from Cheyne-Stoke breathing had relatively normal spirometric and bloodgas results, which is in contrast to the rest of 
the group, where spirometric values were on the average less than $50 \%$ of predicted. Arterial blood gases commonly showed hypoxia and 16 of the patients had long-term oxygen therapy as well (more then 16h/day) (Kjartansson et al., 2001).

In the year 2003 a study was repeated on patients on home treatment with noninvasive ventilation in Iceland. The number of patients in this group had increased up to 116 patients, 74 males and 42 females, mean age 64 years. This increase is due to increased knowledge on the connection between chronic diseases and disordered breathing during sleep which leads to increased referrals to the sleep laboratory and lately more older people are diagnosed and offered treatment. 114 patients were using pressure controlled ventilators and 2 patients were using volume controlled ventilators. 42 patients showed impairment of lung function and were on long-term oxygen therapy in addition to the home ventilatory treatment. None of these patients had a tracheostomy. On average patients used the machine for 7-8 hours pr. 24 hours. 46 patients (40\%) were using a heated humidifier as an addition to the treatment in order to compensate for dryness in nose and mouth (Halldórsdóttir, et al., 2003).

\section{Long-term Oxygen Therapy}

In the late $18^{\text {th }}$ century Joseph Priestly, discovered oxygen (Hall \& Wood, as stated in Dunn \& Chisholm, 1998). Some time later it was used as a treatment for patients in hospital with acute and chronic respiratory failure. It was not until the 1970s that long-term oxygen therapy was documented and accepted, using a low flow rate and low concentration. Consequently portable concentrators also became available (Ring \& Danielson, 1997). In Iceland domiciliary oxygen therapy has been available since 1974. The total amount of patients treated with long-term oxygen in Iceland in the end of the year 2002, are 224 patients (Annual report of the Icelandic oxygen service, 2002). Oxygen has been used as a supplemental treatment to non-invasive ventilation in Iceland since 1987 (Kjartansson, et al., 2001). In 2003, out of 116 patients on 
treatment at home with non-invasive ventilation $42(30 \%)$ of them were on supplemental oxygen therapy (Halldórsdóttir, et al., 2003).

Long-term oxygen therapy is the only treatment which has been shown to improve survival in patients with advanced chronic obstructed lung disease and the longer the daily use of the oxygen is, the better the survival rate (The Nocturnal Oxygen Therapy Trial Group, as stated in Weitzenblum, 1996). Reversal of profound hypoxia of severe chronic obstructive pulmonary disease has been found to reduce mortality, if the oxygen is used for a minimum of 15 hours each day. Correction of hypoxia may have other benefits such as reducing polycythaemia and preventing or reducing progression of pulmonary hypertension as well as increase exercise tolerance (Rees \& Dudley, 1998). The treatment with oxygen, in patients with congestive heart failure with central sleep apnea, have been shown to be beneficial by correcting apnea related dips in oxygen saturation as well as decreasing the number of apneas and decreasing the overnight norepinephrine levels (Tkáćová, et al., 2002).

\section{Technology and Caring in Nursing}

\section{Introduction}

The purpose of this review is to highlight literature on the status and effects that technology has on caring in nursing. This is vital for nurses especially for those who work in highly technical environments and/or caring for patients needing long-term technological treatments. In all fields of the health care diagnosing-, monitoring- and treatment technology is on the rise and in the near future nurses can expect to be caring for patients in need for technology wherever they practice. In resent theories on the interaction between technology and caring in nursing there is an increasing emphasis on the notion of this interaction being very complex and always dependent on the provider of care. Of particular importance is the hands and senses of health professionals/nurses and that the essence of technology per se is not used in a dehumanizing way (Barnard \& Sandelowski, 2001; Gadow, 1984; McConnell, 1998). 
The use of technology in health care raises many ethical and practical questions. In the past decades development in science has been enormous, followed by increased possibilities to save lifes after serious diseases and accidents. When development is fast, as is the fact with health care technology, the risk is inevitably that its brilliant functionality and modern look can blur the focus on the patient who is in need for using the technology. It is never possible to take as a fact that every patient is at peace with the utilization of technology in health care. The handling of technology therefore requires critical thinking. In this review, the literature on the conjunction between the concepts technology and caring in nursing will be reviewed and the effects this may have on nursing practice and the recipients of nursing care. The intention is not to judge or decide what is right or wrong in terms of technological invasions or treatment possibilities, rather to look into the effects this may have on how nurses care for patients and on patient's daily life and their outlook on life.

\section{Main Approaches to Technology and Caring in Nursing}

Several nurse theoreticians have written extensively on the concepts of technology and caring in nursing. The main thread in this literature is the need for reconciliation between those two concepts. Authors view the subject from different standpoints. The majority of authors maintain that in todays healthcare where technology is all around us and as such is an unavoidable aspect, we must find a way to provide caring through the use of technology (Cooper \& Powell, 1998; Locsin, 1995; McConnell, 1998; Ray, 1987). Margaret Sandelowski has been in the lead in research on how technology is utilized on people in health care, and on the utilization of obtained information via technological measurements. She has also looked into the ideology of patient's dependency on technology and how this can oppose the holistic view of the body by focusing on parts of bodies and components of processes (Sandelowski, 1993). Her writings are of much relevance to this study regarding technological dependency. 
Another theoretician who has written about the effects of technology on nursing is the Australian, Alan Barnard. He has criticized how researchers within nursing write about technology and caring in nursing in terms of its neutrality. Neutrality in that sense means that the utilization of technology is always totally responsive to user's preferences and decisions. The neutral belief encourages the view that machines do not make decisions they are there to solve problems. Efficient resolutions are mechanized after humans have discovered the problems. The neutral belief is describes by Mander (Barnard, 1997), as suggesting that there is nothing intrinsic to technology or its circumstances which predetermines how it is used and controlled and what effects it will manifest upon individuals. The attention must therefore be drawn to the person utilizing or prescribing the use of technology to examine the motives and interests at hand. Barnard (1997) however emphasizes, that rather than being neutral technology is a dominating force that is ruled by politics and is a "complex arrangement of machinery, processes, people and systems" (p. 130). In more recent writings (Barnard \& Sandelowski, 2001) a stronger emphazise is placed towards reconsideration of drawing strong lines of differences between the concepts technology and caring. Instead it is suggested that attempts are made to understand the connection between the two concepts. Gadow (1984) maintains that the duality is thought to draw attention to technology as a cause for impersonal nursing care which is not helpful in today's health care, therefore it is nessessary to develop the links between them. Mitchell, 2001 emphasizes the importance of a clear vision on both concepts in order to be able to build up a knowledge base between them and synthesize knowledge into one paradigm, which informs all activities with human beings.

Barnard (2002) points out that nurses are now more than ever before required to undertake roles and responsibilities associated with interpretation and application of technology in the health care. This brings about ethical, epistemological and ontological challenges and questions. When studying the experience of technological 
dependency which is the main concern of this study a discussion of utilization and handling of technology is of vital importance.

Sally Gadow has for the last two decades written on technology and caring in nursing by exploring the meaning of nursing philosophically and ethically, her main theme being the exploration of the nurse-patient relationship. Gadow's (1984) perspective is that technology can only violate human dignity to the extent that its use dehumanizes people. Ethical problems related to technology were explored in Gadow's earlier work by determining the ideal nurse-client relationship and defining the moral responsibilities involved (Hess, 2003).

The stance taken in this study is the notion that there is a need to integrate technology and caring in nursing practice, grounded on the fact that technological utilization calls for human interpretation. Technology never stands alone without human involvement. However, a dilemma exists about the way we approach patients and whether we acknowledge them and work with them on their own terms, or confront them with controlling and judgemental approach. Therefore, in all nursing practice it must be considered that caring has ethical and practical meaning having the fundamental difference of caring as performing tasks (which can be done without caring) versus caring for persons as human beings.

\section{On Definition of Technology}

Various definitions on technology in health care have been put forth and the multiplicity reflects mainly the philosophial/theoretical perspective from which is looked. Heidegger (1977) defined technology as a means to an end, an instrument, as well as human activity and stated that those two belong together. The manifactured tools, the needs, and ends that they serve, all belong to what technology is. Where for example a cardiac monitor means an instrument and the interpretation of the data from the monitor is a human activity. This means that all tests and technical interventions are followed by an interpretation by health professionals and act as a basis for 
maintaining patient's well being (Locsin, 1995). Sandelowski (1993, p. 36) referes to the definition of Bush on health care technology, which includes "people, tools and techniques in organised systems of interaction to achieve human goals". This definition is theoretically similar to the definition of Heidegger stated above. People refers both to the recipients of health care services, as well as nurses, physicians, technicians, sales representatives and repair personnel. Tools include all instruments used from a simple thermometer to a complex CT scanner. Techniques refer to procedures that put tools to clinical use. Organized systems of interaction stand for the delivery systems necessary to develop, disseminate and apply technology such as intensive care units, research and testing programs, genetic counseling and systems to develop manifacture and sell equipments. To achive human goals is typically described as maintaining good health and supporting or extending life (Sandelowski, 1993).

Barnard (1997) critised some theorists writing on technology in nursing and maintaines that they center on the belief that technology is a neutral influence in nursing. The fact is, he maintains, that technology is pervasive influence upon nursing practice, decisionmaking, judgement of individuals and politics. This view is supported in a qualitative study on nurses' understanding of the concept of technology in health care. The results not only describe technology as an essential part of nursing practice, but also emphasise the importance of understanding that technology plays a big part in people's experience of health care (Barnard \& Gerber, 1999). Therefore, Barnard (2000) defines technology not only as technical objects but the knowledge that is needed to manage it. That includes professional desision making, the management of institutions, politics and the assessment of the technology that are to be used. 


\section{Technology and Caring in Nursing}

In this study the definition of caring as described by Gadow (1985) will be used. She defines caring as a commitment to protecting and enhancing the dignity of patients. Sally Gadow was one of the first nurse theorists to write about nursing philosophy and ethics. Her contribution to the literature has been the exploration of the question of what nursing is, and determining the ideal nurse-patient relationship. She has stated that by identifying the moral responsibilities involved in the ideal nurse-patient relationship, ethical problem will then be resolved for the discipline (Hess, 2003). The foundational meaning in Gadow's work on the determination of the ideal nurse-patient relationship is to distinguish between paternalism and advocacy. Paternalism implies coercion in order to provide a good that is not desired by the one whom it is intended to benefit (Gadow, 1980a). Advocacy, however, refers to freedom of self-determination as the most fundamental and valuable human right (Gadow, 1980a). Although this work of Gadow contains a strong statement about resolution of problems within nursing, it has been of importance in directing exploration of ethical issues.

The practice of advocacy involves development of the nurse-patient relationship "as the medium for expression of patient's values" (Gadow, 1989, p. 535). One person can for example be shown dignity being allowed to die in peace, without highly technical interventions when another could regard it as violation of dignity (Barnard \& Sandelowski, 2001). The most important aspect in that respect is for the patient to be given a choice, with the aid of an advocating nurse who is prepared to participate with the patient in finding "the unique meaning which the experience of health, illness, suffering, or dying is to have for" him/her (Gadow, 1980a, p. 81). This is particularly important when patients cannot express their values and choices. With silent patients, however, advocacy involves that the nurse speaks with the patient's voice. In such a situation the nurse needs to have access to the subjective world of the patient, which requires embodiment of nurse and patient, described as the "avenue to subjectivity" (p. 537). Gadow identifies three avenues to the subjective world of the 
patient. The first one is to follow advanced directives expressed by the person while still lucid. In the absence of any prior statement, the second one is through other's beliefs about what the person would decide if still capable. The most difficult situation occurs if no privious statement of any sort exists, then the only way remaining is "the avenue of the nurse's subjectivity" (p. 538). To reach this Gadow maintains that nurses must first disengage themselves as an unfeeling instrument and experience the patients' bodies as part of their own subjectivity. Advocacy therefore involves learning to enter patients'world through embodiment, and the presence of a silent patient more than ever requires a devotion of physical care. She further proposes "that after many days of physical involvement, the nurse will slowly sense where the boundary lies between harm and benefit in the patient's world. More than this can not be known" (p. 540).

Van der Riet (1997), drew attention to technology, including machinery and tools, as becoming overwhelming issues in medical treatment and diagnosis. He maintains that:

In the context of health care, the body is regulated by discourses such as medicine and nursing; and the patients, who are experiencing the world and their bodies in often unfamiliar ways, do not necessarily have control over their own bodies (van der Riet, 1997, p. 96).

Locsin (1995) developed a model on technology, termed machine, and caring competence in nursing. The model is grounded in framework of nursing as caring, by Boykin \& Schoenhofer (1993), and is based on the belief that caring is an essential feature and expression of being human. Locsin (1995) has emphasized that if technology is handled in the spirit of nursing values it allows for reconciling technology and caring, but if not it is only a matter of technical skills. It is in line with and draws from the model by Ray (1987) as machine technology is expressed competently while being grounded in the perspective of nursing as caring. Otherwise technology is simply expressing the conductance of machine proficiency (Locsin, 1995). Locsin (2001) emphazises the importance of technological competency in 
nursing in order to be able to express and provide caring by relevant use of technology. He maintains that "the ultimate purpose of technological competency is to acknowledge persons in their wholness" (p. 89). This is of vital importance for nurses when assisting patients in integrating technological treatment in their life.

Huffman \& Sandelowski (1997) performed an ethnographic case study of professional handling of technology in relation to caring for women under transvaginal ultrasonographic performance. Participants were three nurses, two technicians and one physician. Elements such as preparation, information, communication, delicacy, and coverage of nude were mainly watched. The results showed that two of the nurses and the physician fulfilled the traditional nursing purposes of observation, teaching and comforting, although the physician showed less delicacy in touch and coverage of nude. The nurses bent the technology to nursing purposes. The third nurse was the least experienced and at times she allowed the technology to pull her away from nursing purposes. The technicians were comfortable performing the ultrasonography, but did not relate to patients to the same degree as the other examiners did. This is important information although there are several limitations to this study, such as small sample size. It nevertheless gives indications to the importance of carefully selecting professionals who are capable of meeting needs of patients in highly sensitive situations where technical interventions are provided.

The practice environment of the 21st century is vastly different from those of an earlier era. Technology demands new and higher standards for human activity and thus creates labor. (Sandelowski, 1993). Barnard \& Gerber (1999) describe in a phenomenological study conducted on a surgical ward, the impact technology has on nursing. The results were listed out in the following eight themes and presented with the help of illustrations from the nurses who participated in the study, reflecting significant influences of technology on nursing. The themes are: "machinery and equipment", "changes to skills", "increasing knowledge", "respect and autonomy", "gaining control of clinical practice", "clinical resources of the practice environment must meet the needs of technology", "the need to include the patients' experience and 
clinical presentation" and "alteration to the free will of nurses". These results show the various ways machinary and equipment mediate with the participants their volition and daily practice. Results also show variation in experience that needs further research. The theme, "alteration to the free will of nurses" has especially been taken to further investigation by Barnard (2000). There he discusses the concept of the free will of nurses in relation to time and clinical practice, where technological tasks were identified as one of the primary reasons why nurses lack time to be with patients. Another viewpoint Barnard made regarding this is that meeting needs of medical practice comes first at the expence of human needs. This is in line with earlier work by Barnard (1997) on the critique on neutrality of technology in nursing. There he showed that despite efforts of many surgical nurses, the demands placed on them when controlling and handling technology can orientate their attention and practice away from many important roles and responsibilities regarding patients' needs (Barnard, 2000). A piece from Sheila Carr's poetic expression (Schoenhofer, 2001, p. 3-4) of a patient's plea to be recognized as a human being in a highly technical environment correlates with Barnard (2000).

The part that is me, my mind and soul is in my eyes

These tubes that are everywhere - that is not me.

Don't you realize your thoughts are on your face -

In your touch and your tone of voice.

Ray (1987) constructed a model presenting technological caring, based on the assumption that technology and caring are to be reconciled in nursing practice. The model is based on the results of a phenomenological research on the human experience of caring, where eight nurses working in intensive care- and coronary care units were interviewed. The results showed that the frequent notion of the nurse as a primarily technical agent was absent. The study revealed, on the contrary, the dominance of technological caring described as an ethical process. A dialectical process took place "between a technical-ethical modality of care and an integrated 
techno-ethico-human caring modality" (p. 172) where critical caring was mediated through ethical choice. The results are presented in five main themes. They are: 1 . Maturation - a process of growth. Caring challenges interpersonal relationship. It is a process of getting to know the patient and being confident in one's own knowledge as well as coming to terms with one's own mortality. 2. Technical competence. In critical care units technical achivement is one of the key elements of being a critical care nurse. The nurses need to reach a certain level of confidence in mastering technological environment and machines in order to be able to build up interpersonal relationship with patient and family. 3. Transpersonal caring - involves giving and receiving, a bonding process in nursing. It describes touch and attachment enabling the nurse to meet the patient's fears and to enhance feelings of being safe. 4. Communication - being with patient and family. Talking to patients and families and keeping them fully informed. Good communication between professionals is a presupposition to be able to give proper and reliable information. 5. Ethical decision making. It involves understanding of the patient's suffering and calls for trust and right decisions making. This includes working with conflict of values between life and death, giving aggressive technical care or permitting the patient to die in peace. It was described how the nurse grew in human understanding and experienced how the uses of technology affected the patient.

These results describe the experiential process that nurses go through, where they aim at becoming confident in controlling the technical environment around patients at the same time as they receive full attention and care. This supports ideas by McConnell (1998) who stated that such maturation does not come easily. This, however is a challenge to the future where technological development is constantly increasing, referred to as the revolution of the $21^{\text {st. }}$ Century, in terms of what it means to be a human. Increased capabilities in the utilization of technology do not happen in isolation, however they take place within the culture and oragnizational context of both the user and the provider, a context that is steadily changing. Health care technology is made by people and for people, and the utilization of it must therefore 
be tempered with humanism. The role of the nursing profession should at all times be to facilitate the coalescence of technology and humanism (McConnell, 1998).

In a qualitative study by Cooper \& Powell (1998) of patient's experience of bonemarrow transplantation, one of the participants revealed that patients might be grateful that nurses are prepared to pay attention to how technology is utilized and that they see it as their responsibility. This, the patient maintained, is because nurses are able to show emotional touch and their caring attitude can be experienced at the same time as they handle the technology. This resonates with Gadow's (1984) work who repeatedly has maintained that objectification of patients, for example through impersonal approach and control, is dehumanizing and revealation of empathic touch that reactivates good communication and dignity by a healing person reflects a state of mind of the health professional, rather than something inherent in the tools that are used.

Patients' Experience of Technology

\section{Introduction}

Increased technology in health care and the resulting people's dependency on technology has become one of the most important challenges in nursing practice (Gadow, 1984). The National Center for Nursing Research has identified technology dependency as a research priority in order to highlight people's responses to technology and to prevent detrimental consequences (Hinshaw, Heinrich \& Bloch as stated in Sandelowski, 1993).

The author searched nursing and medical literature on the experience of living life through technology. Various articles were found with different angles to the subject, such as the lived experience on having a pacemaker (Beery, Sommers \& Hall, 2002; Burke, 1996) and being dependent on dialysis (Hagren et al., 2001). The literature on the experience of long-term treatment in the form of non-invasive ventilation and oxygen therapy is however scarce. Few phenomenological studies, and some review 
and guideline articles were found. In this section this literature will be reviewed along with exploration of the concept technological dependency and compliance, starting with discussion on lived experience of disease.

\section{The Lived Experience of Disease}

The lived experience of disease can be called illness. "Illness is the human experience of loss or dysfunction, wheras disease is the manifestation of abnormality at the cellular, tissue or organ level" (Benner \& Wrubel, 1989, referring to Kleinman). Focusing on literature on peoples' experience of disease in relation to the exploration of being dependent on various long-term treatments is important in order to enhance understanding of different obstacles that can affect peoples' possibilities to handle unfamiliar situation.

Prior to any kind of treatment there is some kind of disease. Disease can vary enormously in severity and affect people in different ways. In general, disease causes people to rethink and draw a new map for their life (Frank, 1995). This means that taken for granted notions of oneself breaks down and one's self-understanding changes (Leonard, 1994). Baron (1985) criticizes the common view on the patient as a machine that has broken down. Instead he favours looking at illness as a rupture in the patient's ability to negotiate the world. According to Fassett and Gallagher (1998) it is difficult for patients who have experienced illness, especially a chronic illness, to describe the change from being healthy to being ill. This change represents some ontological crisis and an experience of being different. Frank (1995) proposes that the way to come to terms with this transaction, and that is, to tell illness stories, to absorb others' reactions and experiencing one's stories being shared. This he maintains makes a fundamental difference for the sick person. "Disease talk", where medical language is used, involves measurement of the body wheras "illness talk" regards fear and frusrations of being inside a body that is breaking down. In caring for patients it is vital to emphasize "illness talk". 
Gadow (1980b) views illness as an experience that is essential in human existence as it opens up the possibilities to learn to live in an aesthetic relation to the body. This might be difficult in the case of technological dependency such as wearing a mask connected to a ventilator. The face is considered to represent sensuality and the eyes and mouth show apprehension and expression (Lindahl, et al., 2003). The mask, connected to the ventilator disrupts this expression and for some people that may be difficult to come to terms with.

\section{Theoretical Frameworks of Technological Dependency}

Technologically dependent person has been defined by the federal Office of Technology Assessment (OTA) as someone who "needs a medical device to compensate for the loss of a vital body function and also requiers ongoing nursing care from either a lay person or a professional to avert death or further disability" (Smith, 1996, p. 96). Technological dependency, is defined by Sandelowski (1993) "as the short or long-term reliance, on devices and techniques, to evaluate or, to satisfy or resolve health-related needs or problems" (p. 37). Reliance manifests as an absolute need, as for example in the case of a person who needs ventilator assistance, kidney dialysis or total parenternal nutrition. It also manifests as a singular preference or desire or as a general world-view or orientation as in the case of a professional or cultural bias. Sandelowski (1993, p. 38) further explained dependency on technology involving "the transformation of desires into needs". She referred to the American/Western belief system, regarding technology as the hallmark for the increasing medicalization of American life where it is possible to produce life, delay death and reach out of the limits of nature. In this belief system the body is viewed as a machine reparable by other machines.

Dependency is in itself considered a negative concept. On the other hand independence and self-reliance are considered positive ones. Technological dependency has somehow been reconciled by being conceptually incorporated into 
nature. This is particularly true for infertility treatment, as it has been simulated natural reproductive processes (Sandelowski, 1993). The idea of Fletcher, as described in Sandelowski (1993), that reliance on technology is a part of human nature and in itself exemplifies self-reliance, is supported by many nurses who assimilate technological dependency into the concept of self-care. In home care technological dependency has been presented as being diminished if patients and their families or caregivers can independently manage their care (Smith, Giefer \& Bieker, 1991).

Technological dependency can have short and long-term consequences on peoples' lifes. These consequences can be intended or unintended, be unforseen or by-products of dependency. The intended outcomes normally referred to as positive aspects, include the maintainance of good health, restoration of function, a recovery from discomfort, prolongation of life and improvement in quality of life. The negative side, the unintended outcomes, involves further morbidity and mortality and or a far reached social outcomes, which involves impacts on the person's capabilities and choices (Sandelowski, 1993). Reiser, (in Sandelowski, 1993, p. 39) has identified these side effects as "technocogenic". This syndrome can include various problems due to health care technologies, such as psychosis observed in patients in intensive care units or bronchopulmonary dysplasia observed in ventilator-dependent infants. These side-effects constitue a new set of technologically engendered disorders, coexisting with or replacing the disorder or conditions that led to the use of technologies in the first place. This can call for new technological solutions, or some kind of treatment, which in turn can lead to increased dependency. An example of the technocogenic syndrome is when a primary end-stage renal disease can become an "illness of the dialysis" (Peitzman, in Sandelowski, 1993). The study of Cooper \& Powell (1998) on patients' experience of having bone marrow transplant, described how this treatment both creates and reduces vulnerability, and is at the same time a decision about life or death due to the high risk and uncertainty related to the treatment. 
For some people it might be beyond their power to visualize the machine metaphor as in an obvious opposition with nature (Young, Marshall \& Anderson, 1994). This of course depends on people's abilities and predominant culture. When all aspects are taken into consideration technology can provoke many ethical questions about purpose and significance of treatment (Beery, Sommers \& Hall, 2002; Cooper \& Powell, 1998).

People have different views when it comes to the utilization of technological treatments (Sandelowski, 1993). Some people may choose all possible preventative measures to live as normal life as possible while others choose a lifestyle that is known to be a risk to ones health and can lead to diseases that later may call for technical devices as a solution to recover and maintain health.

The model of technological dependency by Sandelowski (1993) (Fig. 1) shows the possible status of patients when technology is thought to be vital for their health. This model is drawn from philosophical and sociohistoric works on technology in nursing and social science literature, especially in the field of reproductive technology. The purpose of the conceptualization in this model is to aid nurses in recognizing, organizing and in deepening their understanding of technological dependency. It describes the thinking process of people who are confronted with the question whether to accept or reject a technological treatment. The complexity and cultural inscribtion of the phenomenon, technological dependency in health care is summarized in the model as a cause, consequence, or intervening process that is exhibitied in patients and in their caregivers. Sandelowski considers nurses to have a critical role to play in enhancing understanding of this phenomenon and implementing strategies to maximize the value and minimize the harm of technological dependency. The consumers of technology; the patients, neither invent nor have possibilities to control the application of technology. 
Figure 1. A conceptual map of technological dependency in health care

\section{Via anatomization and deflection/masking}

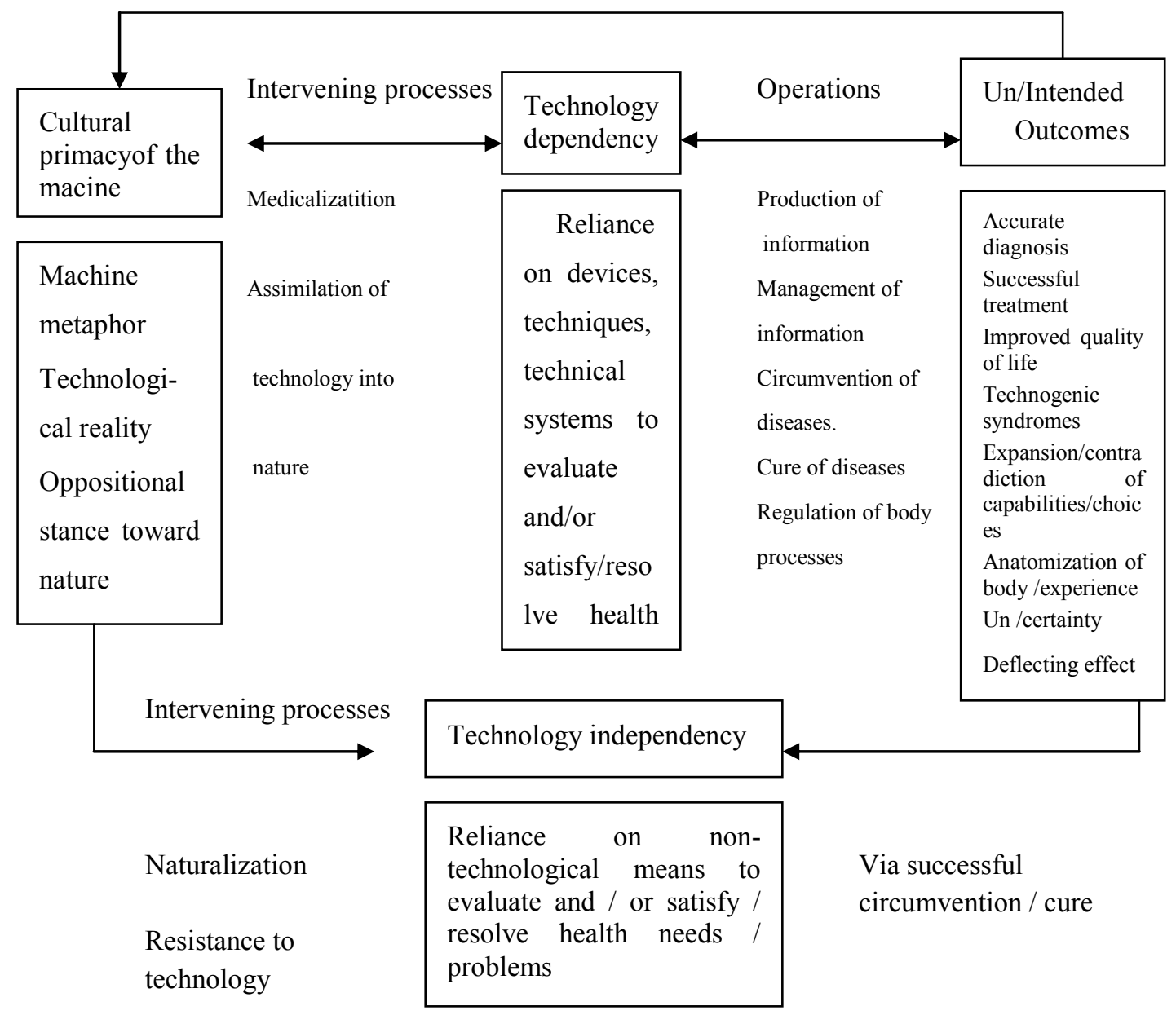

(Sandelowski, 1993, p. 41).

Beery, et al. (2002) studied the experience of women who had undergone a pacemaker implantation. Results supported main premises of the model of Sandelowski (1993). They revealed that some of the participants had doubts that they could see themselves as women after that intervention. A lump can be seen in the area where the pacemaker was implanted and there was also a scar on the chest, which 
made them reluctant to wear certain clothes. Participants described how they fluctuated between this unwanted aspect of technology and the acceptance of the pacemaker and the positive effects of it. The women described how they tried to come to terms with and accept the treatment, by thinking about if they were younger then it would have been more difficult for them. Hagren, et al. (2001) studied the experience of suffering from end-stage renal disease and showed how achievement a sense of personal autonomy and tailoring treatment to each person's needs alleviates suffering of technology dependent patients.

\section{Studies of Technological Dependency of Persons Using Ventilation Treatments}

Research on the experience of ventilator-assisted persons is not a well-established field. The majority of studies on the subject are quantitative and focus on variables such as blood-gases, ventilator parameters, functional status and longevity. Pehrsson, Olofson, Larsson \& Sullivan (1994) conducted a study in Sweden of quality of life in patients with neuromuscular diseases, post-polio syndrome, scoliosis and post thoracoplasty, treated with mechanical home ventilators $(\mathrm{N}=39)$. The research instruments were: The Sickness Inpact Profile (SIP), 136 items grouped into 12 categories, The Mood Adjective Check List (MACL), 38 items catagorized into three dimensions and the Hospital Anxiety and Depression scale (HAD) consisting of 14 items catagorized into 2 dimensions. The results showed that the overall SIP was significantly higher in the home mechanical ventilation group, which indicates greater dysfunction than in the reference population, but the SIP scores for psychosocial functioning did not differ significantly. Neither did the scores of MACL and HAD scales discriminate between patients and the reference group. The results indicated that the home mechanical ventilation patients maintained good psycho-social functioning despite treatment. Nauffal, Doménech, Martínez García, Compte, Macián, and Perpiná (2002) conducted a longitudinal research on quality of life, dyspnoe and blood-gases on patients with kyphscoliosis $(n=27)$ and neuro-muscular diseases 
$(n=35)$, treated with home mechanical ventilators. The results showed that patients with kyphoscoliosis showed improvement in all three items and maintained better health in the long run, compared to the patients with neuro-muscular diseases. Patients with neuro-muscular diseases showed improvement in the beginning in quality of life and blood-gases but the improvement did not hold in the long run. Admissions to hospital decreased significantly in both groups.

Bach, Campagnolo \& Hoeman (1991) studied life satisfaction and general wellbeing of patients suffering from Duchenne Muscular Dystrophy and compared to the perception of health care professionals of perceived life satisfaction and general wellbeing of the same patients. The participants were 82 ventilaor-assisted patients and 273 physically intact health care professionals. 39 of the patients were on noninvasive ventilation, 33 had tracheostomy and ten participants did not indicate the type of treatment they were receiving. The results showed that the vast majority of these severly disabled patients had a positive affect and were satisfied with life despite the physical dependence that precluded many of the activities most commonly associated with perceived quality of life for physically intact individuals. The health care professionals significantly underestimated the patients' scores in life satisfaction and affect and sigificantly overestimated the burden associated with ventilator dependence. This indicates that health care professionals should not use their judgement of the patient's quality of life to justify life-sustaining treatment.

Gelinas, et al. (1998) in a study on seven ventilator-dependent patients suffering from amyothophic lateral sclerosis found that patients reported satisfactory quality of life. They concluded that the ability to successfully adjust to becoming ventilator dependent was not dependent on how well prepared the patient and/or caregiver was before making the decision about the ventilator, but rather was dependent on the strength of the relationship between the patient and the caregiver and the possibility of a good support system for both of them.

A qualitative study by Young, Marshall \& Anderson (1994) explored ALS patients' perspectives on their use of mechanical ventilation and some components of the 
decision-making process. Out of thirteen participants four were using mechanical ventilation, three of them were using a mask and one had a tracheostomy. The use of a mask ventilation was reported to be not as big a decision as choosing a tracheostomy and those stating that tracheostomy was acceptable to them were those already using mask ventilation. This finding indicates that the use of the mask may lead to willingness to consider a tracheostomy when the non-invasive ventilation via mask is no longer sufficient. Some participants didn't think that assisted breathing were acceptable, "I would rather let nature take care of itself" (p.256) one said. The possibility to discontinue ventilatory support was very important to half of the participants. One patient said: "A mask is acceptable besause it could be taken off ... But, if I go into some sort of condition where I'm laying there and say 'Hey, doc, could you shut that off?'...I don't know whether they [doctors] would or not. I'd like to know that I'm in control." (p. 256). Some felt that dependence on a machine for life was unnatural and did not want to become emotionally upset by being kept alive by some equipment and maintained that such a procedure would be an insult to the body. All participants stated that they should make the final decision about the use of a ventilator.

Fitch and Ross (1998) conducted a qualitative study and interviewed eight patients about the experience of being dependent on a ventilator and living at home. The analysis revealed the following topics: Skill in managing the equipment, need for organisation and planning, variations in assistance, experiencing an emotional rollercoaster, struggling with changes in lifestyle, maintaining a positive attitude, the ventilator as an extention of self and preferences for the home environment. The participants described how the ventilator became a part of themselve and they brought the equipment along wherever they went. For them this led to a new definition of "normal", as time went by, dependence on a ventilator for life, was looked at as normal. In a qualitative study by Lindahl, et al., (2003) about the meaning of being dependent on a ventilator and living at home, nine patients with diverse diagnosis, age and functional status participated. The results were described in five main themes and 
sorted into the structure of life-world existentials as defined by van Manen, they are: To experience home as a safe and comfortable space from which to reach out (lived space), to experience the lived body as frail, brave and resilient (lived body), to strive to live in the present (lived time), to surrender oneself and to trust others (lived human relation) and to experience technology as a burden and a relief to the lived body (lived technology relation). The ventilator was seen as a rescuer and efficiently functioning and well-designed equipment made an enormous difference and was experienced as an improvment in life quality.

In a review article by Perkins \& Shortall (2000) authors concluded that the most important way to help patients requiring non-invasive ventilation to adapt to treatment, is to take the time to coach, reassure and explain. They also emphasised the tailoring of education and nursing care considering patients condition and degree of illness and to include family member or significant others in the process of education.

Ring \& Danielson (1997) conducted a phenomenological study with the aim of describing the patients' experiences of self-managing of continuous oxygen therapy along with their view of managing their chronic pulmonary disease. The findings were summarised in four categories. 1) Restricted to time and room. The patients found them to suffer from deficiency in mobility and handling of the equipment, which was an obstacle in several ways. 2) An advantage for the body. "An awareness of the body's need for oxygen helped the patients to accept the treatment" (p.341). This was illustrated as follows: "[Patients] feel when their inner organs need the oxygen and they can observe when nails and lips become cyanotic. The experience of well being in connection with the treatment is of great importance for acceptance of the therapy. At the same time the dependence upon the treatment may be perceived as difficult" ( $\mathrm{p}$. 341). 3) Living in one's own life rhythm. The patients knew their bodies and often knew how to handle specific situations and it was important to them to be able to do things at their own pace. 4) Put up in order to live. Living with oxygen meant to "learn in another way than earlier and adapt to new situations. A longing to live makes it possible to live, to put up with and to tolerate" (p. 342). A close relationship with a 
significant person, a spouse, a child or a friend was of great importance in this regard. This last statement, is supported by Gelinas et al. (1998).

Life security through technological acceptance was a focus in a study by Burke (1996), not on ventilated dependent patient but on the experience of living with a transvenous internal cardioverter defibrillator, during the first 6 months after implantation. The core process was characterised by three major categories: 1) Choosing life with technology. In that phase the patients were going through the process of decision making and imagining how life would be without it. They asked themselves, 'do I want to risk having another cardiac arrest and depend on the resuscitation team to be here in time to save my life?' Expressions of anxiety, apprehension and nervousness were common during that phase. 2) Integrating technology into life. This phase began when patients awoke from surgery and were aware that they had survived the implantation and that now they had to adjust to "make room" for the implant. The goal of this phase focused on regaining, maintaining or enhancing life quality. 3) Living life through technology. This phase involved patients' accepting the implant to the extent that their daily activities and thoughts were directed toward "living".

\section{Compliance - Non-compliance}

Considering the research on ventilated dependent patients it is relevant to explore the concept of compliance/non-compliance. Compliance is a concept of greatest relevation within the domain of home ventilation and oxygen use as an essential part of treating patients with their technique has been a close follow-up on their usage. On these machines there is a timemeter of which a minute-by-minute usage of the machine can be read. In some instances a complete data on the usage of a machine can be traced on a 24 hours basis. This collection of information sometimes called "compliance data" is a very sensitive issue, which needs to be explored carefully. 
Compliance with prescribed clinical prescription or therapeutic regimen has been of concern to health care professionals for decades as it is assumed to be critical for patients' achivement of optimal health (Hess, 1996). Compliance has been used to describe patients and patients' behaviour. It has a negative connotation (Murphy \& Canales, 2001) and is "laden with connotations of paternalism, coercion, and acquiescence" (Hess, 1996, p. 19). This becomes more clear when the meaning of the term compliance and the verb to comply is explored. Compliance according to Merriam-Webster's online dictionary (October 27, 2003) is 1:a the act or process of complying to a desire, demand, proposal or coercion. b. conformity in fulfilling official requirements. 2: a disposition to yield to others. The verb to comply is: 1 : to be ceremoniously courteous. 2: to conform or adapt one's actions to another's wishes, to a rule, or to necessity. The term non-compliance is, on the other hand, commonly used when there is a mismatch between what is prescribed to patients regarding medical treatment and/or lifestyle changes and what patients actually do (Russel, Daly, Hughes \& Corinne op't Hoog 2003).

Non-compliance gets the most attention in the nursing literature. In a critical review Murphy \& Canales (2001) analyzed the literature into the following three categories: Acceptance, rationalization and evaluation. Acceptance indicates that non-compliance is a patient problem to be resolved by a nursing intervention. In this category there is a complete silence about the controversy of the term compliance and no critique is offered. The second category rationalization offers a critique of the term noncompliance, but still carries on using it in the light of its importance to health care issues. Many of these authors rationalize their continued use of the term by explaining how they use it. As such the term survives and is more important to these authors than the problems the term presents. In the third much smaller "evaluative" category, concern about the use of the term compliance is expressed. Authors attempt to reconstruct the concept in various ways to enhance fit with patients' life situation.

Lowry's (1998) writings belong to the "evaluative" category. She approached noncompliance from mental health perspective and argues that as such mental patients 'as 
a whole' are coerced into accepting treatment. Those refusing treatment frequently are labelled as non-complient. Russel et al. (2003) ground their work on the literature in the "evaluation" category as a basis for creating alternative to the intervention commonly directed at patients who do not follow health care professional's advice. This approach encourages nurses to learn how health care treatment affects patients' lives and not merely their health, a patient-centered approach, which takes into account patients' social context. They argue that it cannot be assumed that patients simply choose not to follow advises. Instead authors recognise that patients may be severely constrained by the social circumstances in which they live which consequently influences how or if they are able to follow prescribed treatment.

Hess (1996) is one of the authors who also fit under the evaluation category. Hess questions ethical compatability of compliance with nursing's humanistic philosophy and belief in self-determination. In more resent writings she emphasized the importance of a redefinition of the term compliance emphasizing collaboration and partnership with the patient (Hess, 2003). Hess drew from Gadow's dialectic of ethical knowledge (Gadow, 1999). Gadow's framework includes three levels of ethical knowing. They are: Subjective immersion, objective detachment and relational narrative. The aim is to develop an understanding of ethical knowing as each successive level overcomes the inadequacies of the previous level. The first level the, subjective immersion or immediacy, can be explained as an unquestioned and uncritical certainty about what is right and good. The nurse becomes "immersed in a tradition that provides an ethical appraisal of the situation, as well as immersed in the situation itself" (p. 60). By this the nurse gets an ethical reading of the situation. The second level objective detachment, " provides the distance needed for objectivity, for viewing from a vantage point outside, instead of inside, a situation" (p. 61). This level is in opposition with the immediacy of the first level. It is a rational objectivity and "it commits us to a contract of reciprocity in which we respect the value that they [patients] and we share as universal, free persons"(p. 61). The third level relational narrative is considered an existential turn, "the uniqueness of individuals is their 
essential feature" (p. 62). With other words the nurse values each individual as a unique person. The previous level cannot acknowledge or address this uniqueness. Therefore it is passed on to the third level to relate to the human intersubjectively.

Relational narrative is characterised as "embracing of contingency, refusing certainties, and resisting the modern drive for unity, order and foundations" (Bauman and Tester as stated in Gadow, 1999, p. 63). This involves engagement where the nurse a person reveals his or her authentic being to the patient and within this relationship the nurse is able to grasp the life situation of the person (Hess, 1996). The approach towards creating a relational narrative is described by Hess (2003) "as the construction by patient and nurse of a coauthored narrative describing the good they are seeking, as well as the means to achive this good" (p. 137). In caring for persons who are dependent upon some kind of technological treatment it is important to approach them in a contextual sense; in light of the persons' prior experience, culture, family, environment, situations and longings in life. It is only in context that what a person finds significant or values the most shows up and that is a presupposition in order to be able to understand persons' behaviour and expressions (Leonard, 1994). A response like anxiety can have very different meaning for different persons in similar situations. This has importance for the clinician to be aware of in order to be able to support the patient and family (Leonard, 1994).

\section{Summary}

In recent years, scientific research and constantly improved diagnostic and treatment technology has demonstrated that many patients are suffering the consequences of sleep related breathing disorders. This can both be secundary to various chronic diseases and also be a primary cause, and if left untreated, may lead to untimely morbidity and mortality. The most common treatment for sleep related breathing disorders during the last two to three decades is non-invasive ventilation via facial mask. This treatment has prooved to be successful in majority of cases and has 
the benefit of avoiding intubation. Non-invasive ventilation may have some side effects such as soreness in the face caused by the mask, dryness in nose and mouth due to the blowing of air and some patients find it cumbersome and difficult to handle. Non-invasive ventilation treatment improves ventilation and gas exchange and contractility of the heart. In cases of reduced lung function, treatment with supplemental oxygen may be required which can further improve the survival rate.

In an environment as in the situation where sleep screening is performed and consequently a ventilator treatment is offered and commenced, advanced technology is required. In such a situation it is necessary to consider how technology is handled and that human values are respected. A vast amount of literature is available regarding health care technology and authors are unanimous about the fact that technology in health care makes important contributions to the efficacy, efficiency and quality of health care and quality of life in general. However, a debate is in place regarding the coalence of technology and caring in nursing and how technological environment affects nursing practice. The fundamental difference lies in the way nurses think and act and how strongly they belief that nursing has a unique extistence within the health care. In the light of that belief it is different how authors interprete the caring concept in regard to technology. It has been maintained that technological competency is the directing aspect of the ability to be caring in technical environment.

It is important not to overlook the fact that technology is persistent in today's health care environment. Therefore, in order to uphold caring as the core of nursing all attempts has to be made to reconcile technology into the caring concept.

When patients are facing the fact that they need treatment with technological devices it is vital for nurses to be supportive and caring and value at all times their beliefs, wishes and abilities to undertake in such a treatment. Technological treatment in the form of ventilator assisstance can be complex for people to handle, as it can at the same time be a relief and a burden to live with. The literature is scarce on patients' and families' experience of technology. It appears that disease processes and 
technological devices themselves are thoroughly studied and are gaining even more attention from the health professionals.

The use of the concept compliance/non-compliance in relation to technological treatments is of importance. The paternalistic implication of this concept is obvious and as such it should not guide the way professionals approach patients.

Technology is steadily increasing all around us, and health care professionals must see that as their duty to guard the patients' welfare, when technology has to be integrated into their life. Technology is not neutral, it is a complicated and powerful issue that must be reconciled and postulated in caring. In the light of this literature review, a study like the one that is described in this thesis is highly appropriate. The purpose of this study is to describe patients' and their families' experience of using non-invasive ventilation and oxygen therapy at home. 


\section{Methodology}

The purpose of this chapter is to describe and explain the methodology which is used to answer the following research question: What is the experience of being dependent on technology in the form of non-invasive ventilator assistance, from the patients' and families' point of view? This is a qualitative methodology drawing from interpretive phenomenology and narrative analysis.

\section{Interpretive Phenomenology}

To study the experience of people who are dependent on technological treatment to support life and well being, which is the content of the research question, an interpretive phenomenology was considered an appropriate approach. It helps to reveal what it is to be a human being in a world of illness. To be dependent on technology does automatically interfere with people's environment, culture and family. Therefore it is essential to understand what the patient is experiencing in these circumstances; in other words "what it is to be a human being" in this particular situation (Leonard, 1994). Understanding a phenomenon in its context can enable the researcher to interpret and understand the world of participant's experience. People's life is complex and it is rarely possible to isolate one particular event as an experience of its own. The context must be seen and grasped in terms of history as well as in current situation. Life is a constant movement and the process of understanding the movement is consequently dynamic (Benner, 1994). In everyday lived experience, understanding of health is taken for granted. In illness, that understanding breaks down and ready-to-hand understanding does not apply anymore and a new understanding takes place (Leonard, 1994).

The German philosopher Martin Heidegger (1889-1976) is considered the founder of interpretative phenomenology as philosophy (Drauker, 1999). According to Heidegger's philosophy, as stated in Plager (1994) there are several essential aspects 
for hermeneutic phenomenology as a methology. These include that human beings are social and dialogical beings with certain forstructure of understanding. That understanding, is always before us, in the shared background practices and we are always already in a hermeneutic circle of understanding.

In modern times the nurse Patricia Benner and her co-workers have developed a methodology based on that philosophy. This study draws on the work by Benner and coworkers. Interpretive phenomenology has gained much popularity in the last decade within nursing research where Benner has been a pioneer in its development in nursing (Drauker, 1999). According to Drauker (1999) interpretive phenomenology is appealing to nurse researchers who seek not only to describe lived experiences related to health and illness, but also to understand the meaning of those experiences within the context of everyday lives of people for whom they provide nursing care.

The question about the "meaning of Being" was Heidegger's main question. He found that the question "of Being" had always been removed from "its temporal and historical context to a pure presentness, that is, as an independent, objective entity with absolute properties" (Plager, 1994, p. 65). Heidegger however wanted to uncover the meaning of being of human beings, which he claimed had been covered over by approaches that were reductionistic and objectifying. By doing this Heidegger changed the scientific debate about the essence of scientific knowledge from considering the problems of epistemology to the problems of ontology (Leonard, 1994). Heidegger's philosophy emphasizes that one's existence in the world is highly related to language and cultural traditions and makes sense only against a background of significance, as every human being is born into a culture (Leonard, 1994).

Interpretive phenomenology describes the subjective world. Heidegger describes the difference between the subjective world, the life world and the objective world, the world of physics. The former has meaning, wheras the latter does not (Fjelland \& Gengedal, 1994). This is however not a primary way of looking at things because in every day life people look at things as articules for every day use but secondary they 
appear to have meaning. To understand the meaning of an instrument for example is to know what it can be used for and how it is used (Fjelland \& Gengedal, 1994).

Understanding of a phenomenon as it appears in its own circumstances makes a basis for interpretation of the world of participants and events. The interpreter makes a dialouge between viable issues and experience and imagines the world of the participant. The purpose of studying individuals, events and circumstances, is to understand the world, self and others. The assumption of interpretation is to understand. The researcher goes backwards and forward and reflects on the situation and context of things in order to grasp its meaning. The aim of that is to aid understanding of the phenomena, which then is developed into interpretation (Benner, 1994). According to Dreyfus as stated in Benner (1994) it is taken for granted that the world can't be fully understood. The multiplicity of human situation in the context of circumstances and history can only be studied in a limited way.

\section{Author's Preunderstanding}

The author has through the years assisted people through difficult periods of time in their life when progessive illness calls for long-term technical treatment. The author's experience is that in most instaces people connect to their environment, family, friends and culture when discussing and deciding on what matters in relation to starting and using non-invasive ventilationvalues in life. Literature has supported this notion and emphasized the importance of creating a dialogue between patients and health care professionals to enhance understanding of the patients' situation and the possibilities they have for undertaking treatments.

\section{Sample and Procedure}

Participants were chosen from a group of people living at home who are dependent on long-term, non-invasive ventilation with or without additional oxygen therapy, due 
to various chronic diseases affecting breathing and their spouse or a family member. A purposive sampling was used (Polit \& Hungler, 1997). The main emphasis in a selection of participants was to choose information-rich participants, as the aim is to get a deep understanding of a phenomenon (Sandelowski, 1995). No particular strategies were used to decide on the sample size. It was rather a matter of judgment and experience in estimating the quality of the information collected, against the purpose of the study (Sandelowski, 1995). According to Benner (1994) it is of value to perform repeated interviews with participants rather than to increase the sample size.

The author had some speculations prior to deciding on the inclusion criteria for the participants but ended up with the following inclusion criteria.

The patient was dependent on technology in form of non-invasive ventilation with or without long-term oxygen therapy for at least six months, due to sleep related breathing disorders.

The patient had a spouse or a significant other willing to participate.

The patient demonstrated the ability and willingness to verbalize experience.

Patient was living at home.

Both men and women.

Age 40 - 70

The sample size was adjusted throughout the study depending on the quality of the text. Six patients, 5 spouses and one daughter participated in the study. One of the patients died unexpectedly before the second interview took place. The second interview was taken with the spouse only.

Patients participating were recruited through the Pulmonary Unit at the National University Hospital in Reykjavík Iceland. The head nurse on the ward was asked to choose participants out of a group that fit in the inclusion criteria and ask them for permission to give the researcher their names in order to invite them to participate in the study along with handing out to them information about the study (A. 1). Upon this permission researcher phoned the patient at their home and invited them to the 
study. The researcher went through all information given on the information sheet and emphasized the purpose and procedure of the study and the participants rights to withdraw at anytime, promised confidentiality and possibilities to seek advise and support in case discomfort or questions arise connected to the research (Usher \& Holmes, 1997).

Both patient and family member signed informed consent, before the first interview (A. 2). The interviews were conducted in a place of choice of the participants, in their home, the hospital, the Institution of Nursing Research or any available place of choice. All the participants chose their home as a place for the interview expect one participant who chose to have the first interview taken in the hospital facilities for convenience purposes. The length of each interview was approximately 60 minutes.

\section{Data Collection}

For the purpose of the study it is essential to set the interviews up in a naturalistic way so participants may feel free and unconstrained to express themselves (Benner, 1994). Kvale (1996) suggests that to meet these premises, the researcher needs to keep in mind, that a life world is being studied and the participant's relation to it. It is important to use normal language and expression, without aiming at quantification. As an open nuanced description of different aspects of the subject's life world was sought for, description of specific situations and action sequences were elicited, but not general opinions. The interviewer expressed openness to new and unexpected phenomena and avoided ready-made categories of interpretation. The researcher focused on particulars in experience.

Information transmitted in stories that human beings tell each other have come to be valued in the recent years (Sandelowski, 1994). According to Mattingly and Garro (1994) narrative offers a way to understand life in time and how we make sense of things. It helps make history, and realize whom we are and that our past are a part of our becoming (Mattingly \& Garro, 1994; Polkinghorne, 1995). Telling stories gains 
access to the way the participants understand and structure the situations. Direct first person account, can give a closer view of every-day lived understanding than generalization about what one does or believes. It can matter whether the story told by the participant is being told for the first time or has been told often before. It is thought to be more immediate if it is a first time story, a frequent told story can be more constructed my be rich and include qualitative distinctions and moral concerns (Benner, 1994). Riessman (2002) describes her experience of the participant's need to express them selves by telling a story. She experienced a great resistance from her participants when she made an attempt to fragment their experience in the interview "into thematic (codable) categories", which she described as our attempt "to control meaning" (p.695).

The researcher must be sure that understanding has taken place in the interview. This may be best ensured, by engaged, active listening, which can lead to possibilities of paraphrazing what the participant has said. By such clarification the researcher has to be well aware not to influence the participant's storytelling or asking leading questions. It is important for the researcher to stay close to the participant's account at all times and ensure the patient's opportunity to disagree. It may help to use imaginative and pictorial language and asking the participant for example how they would think certain things looked to others or how they would respond in a particular situation. Such introduction of practical contrasts may enhance fuller account and descriptions of the participant's perspective (Benner, 1994). The interviewer should not suppress the participant's answer by asking too narrow questions. A question like, 'can you tell me how this happened?' Call for a story as an answer. The researcher generates a story "as reminiscences of how and why something occurred or what led to an action being undertaken" (Polkinghorne, 1995, p. 13).

Interpersonal relationship occurs in the interview and if well carried out, it can be a rich experience for the participant, which may obtain new insights into his or her life situation (Kvale, 1996). According to Hutchinson, Wilson \& Wilson (1994) participants in an interview may benefit in various ways. By expressing personal 
feelings one can experience a sense of relief. It can increase self-esteem, counteract feelings of inadequacy and enhance self-awareness. Participants may feel as having purpose by being able to share their story with others. Telling one's story can be empowering and involve movement and change and participants can perceive it as healing. Interviewing can also give voice to persons who have never been able to express difficult feelings. As stated by Frank (1995), telling stories of own disease "is a way of redrawing maps and finding new destinations" (p. 53).

Data was collected with two approximately one hour-long, in-depth interviews with patient and a family member together. The interviews were tape recorded and written verbatim. The author wrote a diary and noted thoughts that came up about the research process as this may increase the validity of the results (Smith, 1999). These notes concerned for example the patients' appearance, surroundings and how the situation affected the researcher. The data collection started straight away after the first phone call to the participants, as their attitude on the phone worked as an indicator on their overall state of being. Then field notes were also written soon after the interviews took place.

The interviews were in the form of in-depth interviews where certain questions were followed (A. 3) and it was also open for topics of concern by the participants. The questions were constructed by taken into consideration five sources of commonalities by Benner (1994), they are: Situation, embodiment, temporality, concerns and common meanings. These commonalities will be described in the following section Analysis of Data.

\section{Analysis of Data}

Data analysis starts in the first interview. Benner (1994) described the first interview as a starting point for interpretive dialogue between the researcher and the participant. This ensures dialogue by allowing the researcher "to pursue lines of questioning that are generated by the study itself". In that sense the collection of data, 
questioning and the analysis of data are not separated (Benner, 1994, p. 107). The meaning of words depend on its context, that is an important subject when reading text that has been written in another epoch or another culture. "The larger the distance between writer and reader in time, social background and culture the greater the problem of interpretation" (p.11). The more similar the social background and culture is between the nurse and the patient the easier it is for them to understand each other.

The interpretation is an ongoing process and through out this process it is vital to be true to the text at all times. The researcher must reqognize one's own preunderstanding before starting the analysis to avoid any predominant views to appear. Misunderstandings and false starts can happen and it is emphasized that this is captured in writing as to be viewed and illuminated and serves as an advance for understanding (Benner, 1994). Interpretation presupposes a shared understanding and therefore has a threefold forestructure of understanding and interpretation that involves the interpreter and the interpreted in a dialogical relationship. This threefold forestructure consists of: 1) "A fore-having": The familiarity we take with us to a situation, the background from our world that make interpretation possible. 2) "A fore-sight": A point of view from our background from which we make an interpretation. 3) "A fore-conception": Due to our background we have certain anticipation for the interpretation (Benner, 1994, p. 72).

According to Kvale (1996), it is important not to loose valuable aspects from the interview like expressions of feelings, silence, laughter and so on. When the interview has been transcribed it becomes lifeless and it is no longer possible to deepen the discussion. Instead the researcher has to, while working on the interpretation, make a dialogue with the text about its meaning.

The meaning can be obvious or hidden in the text. Therefore it is necessary to read the text and listen to the tape over and over to grasp it's meaning. Several scientists have made rules or protocols to follow with interpretation, but the main responsibility lies within the capacity of the researcher. The researcher may have to go beyond what is stated in the interview, when interpreting, in order to find the meaning (Kvale, 
1996). Kvale (1996) talks about several different procedures of interpretation, with different emphasis in analyzing meaning. What these measures have in common is that the researcher reads the interview to get an overall picture, then goes back to certain aspects, considers particular statements concerning specific phenomena and conducts a deeper interpretation. It can be helpful to transform a part of the interview into a narrative to better grasp its content. It may also be of value to use metaphors to aid understanding. It can help the researcher to capture the structure of the text. To increase the depth and validity of the text the analysis is supported by examples extracted from the interview (Kvale, 1996). The goal of interpretive phenomenology is not to uncover private events or understanding, rather to uncover commonalities and differences between participants (Benner, 1994). In interpretive analysis transcribed interviews, observational notes, diaries and samples of human action are treated as text analouges (Leonard, 1994).

In the analysing process, notice was taken of five sources of commonalities (Benner $\&$ Wrubel, 1989; Benner, 1994). These five commonalities are situation, embodiment, temporality, concerns and common meanings. An effort was made to answer the research question through these five sources of commonalities. Situation is understood according to how the person is situated currently and historically. It is important to consider the variety of the situation; is it smooth and pleasant or a breakdown situation? As an example is, that illness presents with a different phase and therefore produces different situations. The way in which the person is involved in the situation affects the reaction presented towards it. Does the person have a choise or is there a way out. Embodiment stands for a view of the body as a whole. "It is the body that first grasps the world and moves with intention in that meaningful world" (Benner, 1994, p. 52). The embodied knowing makes it possible for the person to go through and handle situation and responde to it in a meaningful way. This also applies to early recognition and anticipation of things that may have been experienced before and can be called pattern recognition. Temporality explains the experience of lived time. That is how a person projects him/herself into the future and understands oneself from the 
past. Concern shows the meaningful orientation in the situation. It shows what is noticed and meaningful in the situation; what it is that matters to the person. Common meanings are taken for granted, linguistic and cultural meanings and allows meaningful distinctions and disagreement to occur.

After the interpretation of data was filtered through these five commonalities themes were developed from the text to clarify distinctions and similarities and to consider meaningful pattern, stance or concerns (Benner, 1994). In developing themes narrative analysis was utilized as well (Polkinghorne, 1988, 1995). Polkinghorne (1988) defined narrative as "a scheme by means of which human beings give meaning to their experience of temporality and personal action. Narrative meaning functions to give form to the understanding of a purpose to life and to join every day actions and events into episodic units"(p.11). Further it aids understanding of past events of one's life and planning for the future by providing a framework. According to Polkinghorne (1988) the meaning of narrative refers to "any spoken or written presentation" it designates the answers given in sentences or paragraphs, instead of single words or short phrases (p. 13). Polkinghorne (1995) uses the term narrative to refer particularly to texts that are organized by plots. He defines plots as being the narrative structure through which the researcher describes and understands the connection amongst the events and alternatives of life. The plots can function to mark the beginning and end of the narrative and provide criteria for selecting events to be included. They help with developing the story towards a conclusion and make explicit the meaning events have and how they contribute to the story. Plots, helps to frame the segment of time in which the story takes place and can range from being boundless to daily or hourly episodes. Plots also function to select from vast amount of happenings and the things that led to that happening are the main things for highlighting the story. 
Ethical Issues in Qualitative Research

In all research, certain codes of ethics have to be followed. In this study four major criteria by Christian (2000) were followed. 1) Informed consent was obtained (A. 2) as participants have the right to be informed about nature and consequences of research projects in which they are involved. Subjects must agree voluntarily to participate and their agreement must be based on full and open information. 2) The codes of ethics oppose deception. 3) Privacy and confidentiality were kept. In the codes of ethics it is insisted on safeguards to protect identities of people and research location. 4). Accuracy in data was ensured; inaccurate data are both nonscientific and unethical.

In preparation of this study the whole process of the research and the publication was made clear to the participants. Attepts to meet these criteria are described in the section on sample and procedure in this chapter. All necessary measures were applied in terms of information delivery to the participants and the obtaining of informed consent. The above codes of ethics were followed. The subjects were informed that permission from the ethical committee of the National University Hospital had been sought and permission given. The study was also reported and accepted by the Institution of Protection of Privacy.

Transcription of interviews can involve ethical matters. The interviews may include sensitive matters and the researcher must be precautious not to treat the information in a way that can lead to recognition of the participants (Kvale, 1996). The transcribed interviews were only accessible by the researcher and the teacher and protected on the computer by a password.

In qualitative research there is always a risk of getting deeply involved in the participants life, and it is a certain invasion to their privacy. Before proceeding with the data collection the author went through possible ethical issues related to the study tobic. When people with chronic diseases are involved and one can't expect a full recovery, conversation about this experience can create mixed feelings for the participants. Speculations of the purpose of the treatment can arise and the researcher 
has to be prepared for showing empathy and giving information under such circumstances. Problems can arise with advances in medical science, as technical development is most often a head of legal and ethical development (Fjelland \& Gengedal, 1994). When interviewing couples or family members with the patient, there is a risk of creating tension or revealing conflicts intended to be hidden between persons involved. This means that the researcher had to be prepared for unexpected events to happen in the interview. Nothing of this sort was identified but the researcher had made plans for the participants to be referred to an appropriate therapist in case a need for it existed.

\section{Rigor in Qualitative Research}

Reliability and validity as being central concepts in determining rigor in qualitative research have a long history (Emden \& Sandelowski, 1998) but these aspects are found to be increasingly problematic to uphold in qualitative context. Some writers place a greater emphasis on validity as a criterion of rigor in qualitative research than on reliability, despite the common position that reliability is a precondition for validity (Emden \& Sandelowski, 1998). These matters have been highly debated within qualitative research, reliability in particular, as it has been more related to quantitative methodology. More has been written about validity in qualitative research and the various ways to increase it. Cutcliffe \& McKenna (1999) provide some guidelines to increase validity of qualitative research findings and argue that it is inappropriate to use quantitative terms as measures of credibility. They state that it should be made explicit which qualitative approach was used and also make clear what attempts or methods were used to establish the validity of the data interpretation. Furthermore they encourage researchers to return to the participants and gain verification and finally to have the findings produced reviewed by practitioners. If findings are regarded as meaningful in the light of their experience it is maintained to be the most useful indicator of validity. 
Inappropriate use of interpretative phenomenology has been of concern among nursing scholars. The critique is mainly based on a failure to provide a robust description of the processes of interpretative research and that in-depth discussions of researcher perspectives were lacking (Drauker, 1999). Munhall, according to Smith (1999) emphasizes the need for including ourselves as data and describing the researcher, as a part of every study. Diaries and the field notes are thought of being of great value during data analysis. According to Smith (1999) a diary may increase the validity of a research. 


\section{Results}

Six patients 3 male and 3 female age $45-70$, participated in the study, along with 5 spouses and 1 daughter. Their underlying diseases were Kyphoscoliosis, Sleep apnea syndrome, COPD, Respiratory insufficiency, Tuberculosis sequel and Neuromuscular diesase. Participants hold various employment status: being employed part time, retired and holding a disability status. They all lived at home in own house or appartment. Three of them had help with house cleaning and one had nursing assistance once a week. All were married except one who was widowed. Two spouses worked outside the home. All patients were on treatment with non-invasive ventilation, four had additional long-term oxygen therapy at night only and one for 24 hours a day. The length of being on treatment extended from 7 months to 10 years. The results are described through joint experience of the patients and relatives, although the patients' experience is more dominating.

The main themes that emerged from the data were:

Mixed blessing: Life saving treatment - meaningless exertion

Being in the hands of professionals - compassion and understanding as central

Listening to the body

Wanting to be seen as healthy

Powerful technology

Routine work and effort in maintaining the treatment

\section{Mixed Blessing: Life Saving Treatment - Meaningless Exertion}

The experience of using non-invasive ventilation treatment and oxygen mainly fell into two groups. It was catagorized either as a complete life safer or as meaningless work. Sometimes the oxygen treatment was in the role of the life safer and the ventilator treatment was seen as less helpful and vice versa. This depended on the 
underlying disease and general health condition. In cases of hypoventilation and sleep apnea the ventilator was experienced as a major relief and an absolute necessity for survival. Despite obvious benefits, the treatment was found to be difficult in the beginning as it provoked mixed feelings and a struggle. Tolerating the air blowing from the ventilator under heavy pressure, having the mask on the face and accepting the need for the treatment and the changes that it brought about were the primary difficulties. Participants felt it extremely helpful under circumstances when the breathing is failing and getting ineffective, to force oneself of taking a positive stance towards the treatment. That is necessary to overcome the discomfort that always exists in the beginning.

The following narrative describes the relief brought about by using the home ventilator:

Looking back, I was always tired, especially in the afternoon. I had headaches and I started dosing off and falling a sleep if I sat down. I used to have nightmares when I fell asleep and woke up finding that I was gasping for air. Even when awake, I sometimes found that I could not fill my lungs properly with air. I was sluggish and not able to do what I was used to and my health status was gradually changing.

Once, when I was driving with my family and friends out of town, my wife noticed the car swinging from one side of the road to the other. Everybody paniced. I had not realised how ill I was. After that I figured out that something was wrong and I was diagnosed with a type of neuromuscular disease. At first I did not comprehend what was going on with my breathing when at sleep. But the treatment with the ventilator and the mask came like a blessing to me: I was saved from torture and anxiety. Now I'm able to stay awake and enjoy the evenings, which I was totally unable to before. There is no question about that: I would not be alive and talking to you if I had not got this treatment. I never go to sleep without it, I call the machine "my friend".

Meaningless work and endless doubts about the effects of the treatment was the negative side of the experience. This manifested in a strain and anxiety:

Sometimes I fall asleep without the ventilator. I really can not tell the difference between using it or not. I have been through serious illness in 
my life and sometimes I find it unfair having to deal with the machine every night instead of leaving my life to faith. For me life has lost its former meaning. I find that I am just existing, not living. What a life is this: being dependent on two machines to keep you going? I always use the oxygen. That is easy to manage and it does not disturb my sleep. Maybe I just don't want to admit that the ventilator is doing me good, but I honestly can not tell the difference. It is not just my breathing that is interrupted, my heart is failing and I get breathless with all movements. When getting ready for going to bed I have to muster courage for a while before having the energy to use the machine.

\section{Being in the Hands of Professionals - Compassion and Understanding as Central}

Closely interwoven into the experience of starting and continuing treatment was the interaction with health professionals. Experiencing compassion and empathy from health professionals was of highest significance in terms of becoming successful users of the ventilators.

Careful guidance as to how to use the machines, and being able to take part in the adjustments of the settings, was valued. Consequently, the lack thereof was experienced as hindering successful utilization of the machine. Some felt that they were more secure when the professionals were straigth forward and made necessary decisions with minimal input from patients and families. This approach contributed to a welcomed alteration in lifestyle that in need to be improved. Others found such approach unacceptable. They needed to have the opportunity to express their needs and opinions. They found the professionals sometimes not having enough time to interact with them, rather than not willing to involve them in the decision making process. They sensed the fast paced service and busy athmosphere in the hospital. Everyone was however, thought to be doing his/her best. The importance of the way the use of the machines was introduced to the participants during the acut phase of the disease was seen as pivotal. That set the stage for what came later.

The following narrative expresses the importance of understanding people in context:

When I was recovering from my disease it became clear that I needed a home ventilator during the night and oxygen therapy for 24 hours a day. 
This was remarkably hard for me to accept and I had doubts about myself. I was used to travel a lot and go out with friends. I was feeling frustrated because I didn't have any options. I was given strict orders. After I came home the treatment started to become difficult to live with. I had a chance to get a second opinion and talk things through: My treatment was set up in a slightly different way, - it was tuned into my pattern of life. When I reflect on it I understand better my perception. Now, I am not worried about being seen as a failure since I only experienced understanding from the professionals, which made all the difference to me. Today I feel well and I do what I am capable of doing.

To be able to phone the hospital unit for advise when needed and having the possibility of renewing the tools if anything breaks down was seen as creating a feeling of safety. The use of technology was not seen as preventing professionals in being caring. The technology belonged there and would be essential in the future. However, there were some stories told that revealed the prominence of the technology over the attendance of the human being.

They are expressed in the following narrative.

I remember when I was recovering from the pneumonia. I found the treatment very difficult. I was weak and frail and right at the beginning I had to stay on the BIPAP machine for 24 hours. I found the mask uncomfortable. There were little things that mattered to me at the time. For example, I was very sensitive about my outlook and wearing the mask made me feel in mess. I did not ask the nurses to make me tidy and it was not their fault that I felt this way.

The things the staff worried about the most was whether my oxygen saturation was sufficient and whether I was recovering well. I remember expressing my will to stop this treatment. After a while I settled on finishing the treatment plan, but this is a bad memory. Of course it was all very important, but maybe I needed a different approach: I wanted them to talk to me more and give me a chance to express myself. I was too ill and not in the shape of making requests for myself.

Here is a story from a daughter:

After my mother came to the unit from the intensive care she lay there connected to a BiPAP machine, oxygen and various other tools. I did not know what this treatment was doing for her and nobody told me. The nurses were running in and out of the room checking on the tools. They 
were obviously very busy. I wasn't brave enough to stop them and ask if I could be told something about all of this. It may sound strange but I thought that according to how busy they were that somebody would die in the next room in the meantime if I would take up their time.

Her mother lived on her own and was capable of looking after the treatment herself. But the daughter who was her significant other had not been given a chance to participate in the treatment. She was the one who needed to reassure her mother after all she had been through. She however found herself being unable to do so in the way she wanted to.

\section{Listening to the Body}

Early on participants became seriously ill, sometimes repeatedly, without realizing what was going on in their body. They had several symptoms of disturbed breathing during sleep without having a clue of what was happening. The perception of the treatment was expressed as a turning point in life. They gained a new vision of their health, and lived experience of the body changed.

The following story illustrates the process a participant went through when learning to read messages from the body:

I would not have become as sick as I was, when I was hospitalized twice during one year almost in coma, if I had known more about how my body functions. I had for a long time been unable to walk more then few meters without becoming breathless. I smoked heavily and paid no attention to my weight. At that time I had no idea why I was so sleepy and had absolutely no energy. I wish I had been told more firmly and in a more comprehensive way about the risk of my lifstyle the first time I was hospitalized. Instead it was left to me to overcome my blindness towards my body. It was not until I was brought in once more in respiratory failure that some drastic actions were taken. This time I was not allowed back home. I was discharged straight into rehabilitation where I participated in an excellent educational program. I am well aware of any changes in my condition now. I watch my diet, I use the ventilator regularly and I take care of not being under too much strain. 
The participants also became masters in fine-tuning the machine and they were sensitive to when the treatment was not effective enough. The following narrative expresses how participants used bodily messages to lead them to adjust the use of the machines to changing condition of the body. This was considered as having a private hospital at home, as the following story revealed:

When I got a flu few months ago, it affected my breathing very badly. I increased the use of the treatment straight away from night-time use only to 24 hour a day for few days. I was very quick to realise what was going on. The doctor who came to see me said that all these lifesaving tools had enabled me to stay at home and if I had not used them the way I did I would have had to go to a hospital. He only gave me some antibiotics and I managed to get through the flu.

\section{Wanting to Be Seen as Healthy}

Not being seen with the oxygen tank and the ventilation mask, nor even revealing the notion that they might be in need for something like that was an issue for participants. This was experienced as a battle as it was threatening their role as healthy persons who were capable of taking part in activities of life. One woman said that she would never go among people with the oxygen because it would give false information about her health; "People would say: 'Poor thing, she must be very ill'. But there is nothing wrong with me in that sense." She didn't find it disturbing to bring the oxygen with her to the physiotherapist, because there she felt the need for it and it belonged there. "I don't like when people ask questions and indicate that I might be ill. This puts me off and I am reluctant to go out especially after the oxygen was added on. I will rather not having to carry this machine case because I know that many people will recognise it". The participants were also sensitive about the mask leaving marks on the face during the day affecting their looks.

The following narrative explains the perceptions when socializing:

I am very reluctant to leave my home. It is partly due to my disease as I have very little energy to do anything. But it is also due to the fact that I don't want people to see me with the oxygen. I don't like when people stare at me. They definitely think that I have been smoking myself to death, but the fact is that I have never smoked in my life. I had 
Tuberculosis when I was a young girl and I was treated with an operation on my chest. I have always managed to look well and it is important to me to keep that. Now, fifty years later my disease is affecting my breathing with these consequences.

Other participant took an opposite stance towards the treatment and saw it as a challenge in life. He told his story in the following way:

I smoked heavily and I am far too heavy and that is what is causing my problems. This treatment is what makes me healthy. I can see no reason to hide that and I tell everyone about it. It might be good for others to see how such a lifestyle affects people. The treatment gives me a new life and possibilities to live life fully and I am not embarressed about that.

\section{Powerful Technology}

Despite the fact that the utilization of the machines was not always helpful for participants it did not occur to them to discontinue the treatment. The dominance of the benefits of technology seems to be overreaching and the participants could not recall having been asked in the beginning whether they were willing to, interested, or capable of using the machines. Instead they explained it as a process that was started and one thing followed another.

I was not really asked whether I was willing to use the ventilator or not. I had a sleep screening and was consequently told that I needed a ventilator to keep me going and to prevent being hospitalized again in the same condition. I had never heard of such a treatment. Would I really need such a dramatic and powerful treatment all of a sudden? This thought was overwhelming in the beginning. I set the treatment aside for one month and tried to convince myself that I did not need it: That I had been without it all my life, despite my progressing disease and I might as well be without it in the future. But finally we became friends, I realised that I could not be without it. In my case it gave a very quick relief. It was just a matter of getting used to it and to accept it. It however often crosses my mind that one day the machine might take over and when I think about it I keep taking deep breaths as I am trying to let this not happen to me. 
The final point that this participant made reveals the threatening notion that technology might take over one day. The feeling of loosing control over the body and not being in charge of what goes on was worrying to participants.

\section{Routine Work and Effort in Maintaining the Treatment}

The usage of the home ventilator and oxygen not only requires work but it also puts limitations on several daily life and recreational activities. The work it requires relates to the mask, headgear and tubes, which have to be kept clean and filters changed according to a protocol. The mask needs to be well fitted and it may take a while to settle it properly on the face when going to sleep. The machine takes up some space. Its visibility to others depends on whether it is needed for 24 hours or during the night only. All of this was in one way or another expressed as some constraint by the participants, even though they had accepted the treatment and have found benefits from it.

Users of oxygen compressors placed it outside their bedroom during night due to the noice it made, which even could disturb next-door neighbours. Guidelines and information given prior to oxygen therapy were seen as rather strict as regards to fire hazard. Participants found the treatment affecting their capacity to travel and some experienced withdrawal, which led to isolation. The spouses and family members were sympathetic and assisted with carrying the tools when needed. They had adopted a certain routine in the maintenance of it. One of the spouses slept in a seperate bedroom for some time to regain a lost sleep due to the noise from the machine and the mask. Some of the participants took the preparation of the mask as a normal process of going to sleep, especially those who had been on the treatment for many years, but others had problems with overcoming the strain involved.

The following story reveals the anxiety caused by the workload related to maintaining the treatment:

I find that I am deliberately postponing going to bed because I dread putting the mask on. The event "going to bed" is making me anxious and I find endless things to do, for example watching television until late at 
night. I try to be extremely tired when I put the mask on so I don't have to stay awake with it on. 


\section{Discussion}

The results show that participants' experience of being treated with noninvasive ventilation varies from being treated as means towards an end which is better breathing pattern and blood gases to a caring concern for the patients' well being where dignity and respect for individual unique needs are at the foreground. Regardless of these different approaches the application of the instruments became reconciled into daily life of participants. In the beginning, difficulties were prominent and extensive. With advanced stage of some diseases however the benefits faded and meaninglessness surfaced.

The main themes that emerged were: 1. Mixed blessing: Life safer or a meaningless exertion. In being a life safer the treatment created new possibilities for people and enabled them to enjoy life more fully. When the constraints overshadowed the benefits, the underlying diseases had come to an advanced stage and death was imminent. 2. Being in the hands of professionals - compassion and understanding as central. Caring approach by health professionals was seen as central to successful use of the technology, but a lack of caring impeded or prolonged successful utilization of the machines. 3. Listening to the body. Participants became increasingly more aware of messages from the body after commencing the treatment, for example changes in oxygen saturation. 4. Wanting to be seen as healthy. The treatment affected life in the sense of threatening the participants' view of themselves as healthy persons due to its visibility. The treatment was also experienced as provoking feelings of being healthy despite the visibility of the machines. 5. Powerful technology. The treatment was experienced as forceful. Even though benefits were not as expected it was hard to reject it. Participants sensed the strong faith that health professionals had for the use of the treatment and didn't want to go against it. 6. Routine work and effort in maintaining the treatment. Daily control of the machines and the accessories required some effort and was experienced by some as a constraint. Participants' spouses and 
family members welcomed the treatment into their lifes and they shared the maintainance work it requiered and were helpful and supportive.

Living with non-invasive ventilation treatment was a constraint for participants in various ways. The extent to which they were able to welcome the treatment into their lives was, on the one hand, effected by the benefits that they received in terms of keeping symptoms of sleep related breathing at minimum. On the other hand was the physical and mental strength that the participants possessed to handle this intrusive treatment. This indicates that there are always some patients that either are not capable of or are not ready to adapt to this technology despite good outcome measures. The literature has repeatedly demonstrated extensive benefits of non-invasive ventilation and has to a much less degree attempted to study if and then how discomfort exists. Studies on quality of life of patients treated with home ventilation show good psychosocial functioning and mental wellbeing in spite of physcical limitation and dependence on nocturnal ventilation (Bach, et al., 1991; Pherson, et al., 1994). The majority of studies have focused on measuring physiological parameters like heart rate, breathing pattern and blood gas levels (Goldberg, Leger, Hill \& Criner, 1999) but not accounted for the peoples' experience of incorporating the treatment into their lives and then living life with this intricate treatment. An exception to these studies, is a study by Fitch \& Ross (1998) on the experience of patients receiving ventilation by the way of tracheostomy, demonstrating prominence of emotional transition and struggles with life style changes for the purpose of holding up a positive attitude. A study by Lindahl, et al. (2003) on the experience of ventilator dependent patients where the majority of participants were on non-invasive treatment has the most relevance regarding daily living with such treatment. Results indicate that the meaning of living with the treatment is laden with aesthetic and ethical values that impact the lived body at the same time as it brings safety and courage into daily life, which is in line with results form this study. This study add depth to the experiental component of living with ventilated assisted breathing supporting the notion that there exist constraints, even 
discomfort, due to the treatment for some participants with end stage disease. Eventhough constraints of the treatment were apparent these results do not diminish the importance of the extensive gains that a person with sleep related disorder can receive from the treatment.

In the hospital, during the acute phase when the technology was implemented, the extent to which health professionals were caring turned out to become a central issue for the participants. Being trapped in a machine for 24 hours was seen as hindering human touch, thus meeting the need of medical practice rather than nursing (Barnard, 2000). It is not to say that the medical treatment was not necessary in that situation, but the nursing care appeared to be halted by the dominance of technology.

Professionals need be aware of the tendency to praise new technology and at the same time overlook other possible solutions (Sandelowski, 1993). A tendency could be seen in this study to carry on the treatment when its benefits were not clear. It is sometimes hard for health professionals to accept that technology known to be advantageous may not always help and can even place extra burden on people (Sandelowski, 1993).

One participant in this study experienced being confronted with a treatment that she could not fit into her context of life. She experienced the treatment as an invasion into her life. She found a way out of the situation when she talked to a professional who was ready to redesign a treatment plan according to what she could manage. There was little difference between that treatment plan and the one that was prescribed for her earlier, but the most important thing for her was that she was given the chance to voice her wishes and possibilities and fit the treatment to those. The advice she received was fitted to her beliefs, life situation and social context which avoided judgements of non-compliance, which is generally referred to under the circumstances of incongruence between prescribed treatment and what the person performs (Russell, et al., 2003). Working in this way is articulated in the work of Gadow (1980a) as advocacy. It refers to the freedom of self-determination, as the most fundamental of human right. Built on similar principles a specific nursing intervention has been 
described where the nurse travels with the patient through the path of illness in order to assist him or her to find possibilities within the illness process (Jónsdóttir, 2001).

Some participants feared that technology might one day take over when morbidity increases. At the same time worries about not having the power to stop that process were expressed revealing thoughts of total dependency on technology. Despite these thoughts the participants seemed to focus more on the helpful side of the treatment and the need to have positive thoughts towards it, which was further encouraged by their family members. Thoughts of total technological dependency are understandable in the light of the technological favor of today. A study by Young, Marshall \& Anderson (1994) on patients with neuromuscular disease revealed this notion. Participants expressed how they sat their limits towards the utilization of technology. They wanted to be in charge of their body and let nature take care of it. They therefore put limits on the extent to which the machines would be used in their individual treatments.

To includ the family in the treatment process, was expressed by the participants as enhancing their supporting role. When a long-term treatment has been prescribed to a patient the process of communication with the patient and family is of importance in order to enhance optimate results physically and psycologically. A good support at home has been shown to be a predominant factor for successful home treatment (Gelinas, et al., 1998).

The treatment unavoidably affected the patients' families. Acknowledging them as participants in the treatment process was perceived as caring as was of highest importance. This is in line with opinions that technology should be interwoven in caring if practiced within the framework of nursing (Locsin, 1995). Home visits and phonecalls by the nurses and the accessibility at the hospital when something went wrong was praised by the participants and was considered even more than they could expect from the health professionals. This was seen as fostering safety in light being discharged from hospital without having fully comprehended how to manage this complicated treatment. Nowadays there is a demand for shorter stay in hospital as 
well as fewer staff on duty. This is affecting the people as seen in this study. This is bound to affect the service in hospitals as increased technology that is a fact within today's health service, creates rather than saves labour as it "creates new and higher standards for human activity" (Sandelowski, 1993, p. 40).

Wanting to be seen as healthy emerged from the interviews. In fact the participants did not think about themselves as patients, and some of them even avoided situations that could indicate a long-term disease by keeping the treatment out of sight of others. Their preconception on health revealed in the notion of health as reflected in the life process rather than in conventional thoughts of health as absence of diseases (Newman, 1986). The disease in that respect becomes a part of the reality of daily living, rather than a temporal problem. Viewing disease as a part of daily life is a challenge for health professionals. Progression of disease symptoms took place subconsciously; they gradually became worse and participants adapted and took them for granted until an event suddenly happened and they needed to take action; something had to be different. In such a state of change participants needed to develop a new insight into their health (Leonard, 1994). Expression of diseases may not necessarily be experienced as symptoms. Rather, it can be revealed as interuption, inconveniences or worries. Curing of disease does not automatically cure the illness, that is, how people experience their body and health (Benner \& Wrubel, 1989). The treatment in itself can also even develop into a new disease and has been termed the "technocogenic syndrome" (Sandelowski, 1993). In this study this phenomenon could be seen as being expressed in worries and anxiety following the event of going to bed.

Being able to read messages from the body has significance in terms of fine tuning of the treatment to each individual needs. Patients needed to recognise symptoms indicating increased morbidity, which could be due to either worsening of the disease or disfunctioning equipments. This can be helpful in order to be proactive in cases of deterioration and can also contribute to some periodic freedom from the use of the machines. Being able to read messages from the body can lessen the burden caused by the treatment in instances when patients can sense e.g. that they can temporarily 
discontinue treatment without causing harm. In this study some participants were experimenting with temporal discontinuation of treatment by themselves. Uncertainty about these limits was an issue associated with traveling. The possibilities of brief discontinuation of non-invasive ventilation or oxygen therapy do depend on the underlying disease and whether the patient is totally dependent on the treatment for 24 hours or only partially. A study on a brief discontinuation of non-invasive ventilation in patients who were affected by chronic hypercapnic respiratory failure and were well established on the treatment showed that only five out of eleven participants showed worsening in arterial blood gas levels and were reconnected to a ventilator before the 6 days study period was over (Karakurt, Fanfulla \& Nava, 2001). This is important in light of the success with experimenting in brief discontinuation of the treatment.

Inconveniences caused by big and bulky equipments dominated participants' experience. Traveling was seen as difficult and the thought of bringing these tools along was offputting. This was particularly difficult in cases of disability when they also had other aids to carry. To have modern looking tools was thought to be of value for the participants and a lack thereof affected the patients' self image, which correlates with other studies (Lindahl, et al., 2003).

The oxygen machine was usually more of a problem than the ventilator due to the size and noice of the equipment. To have a night time oxygen added to the ventilation treatment did not add much extra strain on people if the compressor could be stored in a safe place in the house where it was not obvious or disturbing with noice and could safely be left behind when travelling.

Implications for practice

In treatment facilities for ventilator dependent patients a constant evaluation regarding practical procedures and critical considerations of ethical matters towards the utilization of technology have to take place. The results suggest that a broad 
approach to practice needs to be taken. When introducing the possibilities of the treatment to the patient it needs to be approached from the perspective that he or she is an active participant in the decision whether to take on the treatment or not. The option of stopping or revaluating the treatment in the case of too much burden or increased morbidity needs to be a part of the process of commencing the treatment. Giving advises and recommendation needs to be done in a delicate way. It is defined as paternalism when acts and attitudes are those towards the individual that limits the liberty or rights for their own interest (Gadow, 1980a).

Professionals are constantly faced with demands of efficiency. That is of course the responsibility of all professionals. However when new knowledge and technology is constantly being launched it calls for professionals to be able to uphold standards of careful utilization of innovations. In the field of sleep research and ventilation treatment there has been a total breakthrough for the past years. Scientific research of the harmful consequences of untreated breathing disorders during sleep, have affected many areas of the medical field and referrals to sleep laboratories are constantly increasing. The increasing number of patients with more detailed health problems, call for more intensive support from the health care.

This study has revealed that incorporating non-invasive ventilation into life was difficult for participants in one way or another. Its success depended on careful initiation of treatment both regarding adjustment of detailed settings on the ventilator with following support and training. Giving patients time to express their opinions towards the treatment is part of the process and being ready to engage in ethical conversation and acknowledge the opinions each patient has towards the treatment is valuable. To engage in such dialogue can open up previously hidden dimension to the subject. There can be a discrepancy between outcome measures of the treatment and patients' lived experience of the benefits and this can provoke questions by the patient on the purpose of the treatment. There is a need for the team of physicians, nurses and technicians working in the field to engage in ethical conversations to be able to strengthen each other and uphold notions on caring and the effects of technological 
dependency on patients. Treatment clinics serving patients in need for breathing assistance need to have a clear theoretical framework as to be able to uphold ethical principles regarding support to patients and their families.

More detailed and comprehensive information on disease and body functions needs to be a bigger part of practice and performed in a way that fits each individual involved. This should be considered in the acute phase or as soon as patients condition allows. It is common that patients suffering from hypoventilation with distrubed gas exchange, which is the group that this study is directed towards, are admitted acuetly in the beginning. It needs to be continuality in the allocation of information according to patients' condition.

Non-invasive treatment, like assisted ventilation with a mask, is always depended on the patient himself to continue and it has to be valued, reflected on and worked on regularly. It calls for energy and strength from the patient and it is important to provide support and have a clear accessibility to the clinic when needed.

Reevaluation of the treatment needs to be done after recovering from acute phase as to keep up maximal effects and comfort of the treatment. This is important in the cases of improved lung function and weight loss. This is also important in order to meet patient's questions on the purpose of the treatment and to lessen possible burden caused by intensive treatment.

The duty of professionals working in the field of home ventilation extends to giving information to other fields within the health service as this is a relatively new treatment, is very specific and not a well-recognized field of expertise (Lindahl, et al., 2003). This can lessen uncertainty and fear when patients receive health care elsewhere as was an experience reported in this study.

The author's wishes are that this study has added some insight into the life world of patients adapting to and living with technological treatment in the form of noninvasive ventilation and oxygen therapy at home, and the importance of caring communication with the patients and their families. The hope is that this study can also have implications in other fields of health care. 


\section{References}

Acosta, B., DiBenedetto, R., Rahimi, A., Acosta, M. F., Quadra, O., Van Nguyen, A. $\&$ Morrow, L. (2000). Hemodynamic effects of noninvasive bilevel positive airway pressure on patients with chronic congestive heart failure with systolic dysfunction. Chest, 118 (4), 1004-1009.

Annual report of the icelandic oxygen service (2002). Reykjavík: The National University Hospital.

Bach, J. R., Campagnolo, D. I. \& Hoeman, S. (1991). Life satisfaction of individuals with Duchenne muscular dystrophy using long-term mechanical ventilatory support. Amereican Journal of Physical Medicine \& Rehabilitation, 70 (3), 129-135.

Barnard, A. (1997). A critical review of the belief that technology is a neutral object and nurses are its master. Journal of Advanced Nursing, 26, 126-131.

Barnard, A. (2000). Alteration to will as an experience of technology and nursing. Journal of Advanced Nursing, 31 (5), 1136-1144.

Barnard, A. (2001). On the relationship between technique and dehumaniztion. In R. C. Locsin (Ed.) Advancing technology, caring and nursing. Westport, CT: Auburn House.

Barnard, A. (2002). Philosophy of technology and nursing. Nursing Philosophy, 3, 1526.

Barnard, A \& Gerber, R. (1999). Understanding technology in contemporary surgical nursing: a phenomenograpic examination. Nursing Inquiry, 6, 157-166.

Barnard, A. \& Sandelowski, M. (2001). Technology and humane nursing care: (ir) reconcilable or invented difference? Journal of Advanced Nursing, 34 (3), 367-375.

Baron, R. J. (1985). An introduction to medical phenomenology: I can't hear you while I'm listening. Annals of Internal Medicine, 103, 606-611.

Beery, T. A., Sommers, M. S. \& Hall, J. (2002). Focused life stories of women with cardiac pacemakers. Western Journal of Nursing Research, 24 (1), 7-27. 
Benner, P. (1994). The tradition and skill of interperative phenomenolgy in studying health, illness and caring practices. İ P. Benner (Ed.), Interpretive phenomenology: Embodiment, caring, and ethics in health and illness (pp. 99-127). Thousand Oaks, CA: Sage.

Benner, P. \& Wrubel, J. W. (1989). The primacy of caring: Stress and coping in health and illness. New York: Addison-Wesley.

Berger, K. I., Ayappa, I., Chat-amontri, B., Marfatia, A., Sorkin, I. B., Rapoport, D. M. \& Goldring, R. M. (2001). Obesity hypoventilation syndrome as a spectrum of respiratory disturbances during sleep. Chest, 120 (4), p. 12311238.

Boykin, A. and Schoenhofer, S. (1993). Nursing as caring: A model for transforming practice. New York: National League for Nursing.

Bresnitz, E. A., Goldberg, R. \& Kosinski, R. M. (1994). Epidemiology of obstructive sleep apnea. Epidemiological Review, 16, 210-227.

Burke, L. (1996). Securing life through technology acceptance: The first six months after transvenous internal cardioverter defibrillator implantation. Heart \& Lung, The Journal of Acute \& Critical Care, 25 (5), 352-366.

Christians, C. G. (2000). Ethics and politics in qualitative research. In N. K. Denzin and Y. S. Lincoln (Ed.) Handbook of qualitative research. (2. Eds.) (pp. 133162). Thousand Oaks, U.S.A.: Sage Publ.

Claman, D., Piper, A., Sanders, M., Stiller, R. A. \& Votteri, B. A. (1996). Nocturnal noninvasive positive pressure ventilatory assistance. Chest, 110 (6), 15811588 .

Cooper, M. C. \& Powell, E. (1998). Technology and care in a bone marrow transplant unit: Creating and assuaging vulnerability. Holistic Nursing Practice, 12 (4), 57-68.

Cutcliffe J. R. \& McKenna, H. P. (1999). Establishing the credibility of qualitative researsh findings: the plot thickens. Journal of Advanced Nursing, 30 (2), 374-380.

Dellborg, C., Olofson, J., Midgren, B., Caro, O., Skoogh, B-E. \& Sullivan, M. (2002). Quality of life in patients with chronic alveolar hypoventilation. Europian Respiratory Journal, 19, 113-120. 
Dixon, J. B., Schachter, L. M. and O'Brien, P. E. (2003). Predicting sleep apnea and excessive day sleepiness in the severly obese. Chest, 123 (4), 1134-1141.

Draucker, C.B. (1999). The critique of Heideggerian hermeneutical nursing research. Journal of Advanced Nursing, 30 (2), 360-373.

Dunn, L. \& Chisholm, H. (1998). Oxygen therapy. Nursing Standard, 13 (7), 57-60, 63-64.

Emden, C. \& Sandelowski, M. (1998). The good, the bad and the relative, part one: Conceptions of goodness in qualitative research. International Journal of Nursing Practice, 4, 206-212.

Fassett, D. \& Gallagher, M. R. (1998). Just a head, Stories in a body. Australia: Allen and Unwin.

Fitch, M. I. \& Ross, E. (1998). Living at home on a ventilator. Canadian Association of Critical Care Nurses, 9 (1), 18-24.

Fjelland, R. \& Gengedal, E. (1994). A theoritical foundation for nursing as a science. In P. Benner (Ed.). Interpretive Phenomenology: Embodiment, caring, and ethics in health and illness (pp. 3-25). Thousand Oaks, CA: Sage

Flemons, W. W. \& Tsai, W. (1997). Quality of life consequences of sleep-disordered breathing. The Journal of Allergy and Clinical Immunology, 99 (2), 750-756.

Frank, A. W. (1995). The wounded story teller: Body, illness and ethics. London: The University of Chicago Press.

Gadow, S. (1980a). Existential advocacy: Philosophical foundation of nursing. In S. Spichler and S. Gadow (Eds.), Nursing: Images and ideals, opening dialogue with the humanities (pp. 79-101). New York: Springer Publishing Company.

Gadow, S. (1980b). Body and self: A Dialectic. The Journal of Medicine and Philosophy, 5 (3), 172-185.

Gadow, S. (1984). Touch and technology: Two paradigms of patient care. Journal of Religion and Health, 23 (1), 63-69.

Gadow, S. (1985). Nurse and patient: The caring relationship. In A. H. Bishop and J. R. Scudder, Jr. (Eds.) Caring, curing, coping. Nurse, phyisician, patient relationship (pp. 31-43). University of Alabama Press: Alabama. 
Gadow, S. (1989). Clinical subjectivity, advocacy with silent patients. Nursing Clinics of North America, 24 (2), 535-541.

Gadow, S. (1999). Relational narrative: The postmodern turn in nursing ethics. Scholarly Inquiry for Nursing Practice: An International Journal, 13 (1), 5769.

Gelinas, D. F., O'Connor, P. \& Miller, R. G. (1998). Quality of life for ventilatordependent ALS patients and their caregivers. Journal of the Neurological Sciences, 160 (Suppl. 1), S 134-136.

George, C. F. P. (2001). Reduction in motor vehicle collisions following treatment of sleep apnoea with nasal CPAP. Thorax, 56, 508-512.

Goldberg, A., Leger, P., Hill, N. \& Criner, G. (1999). Clinical indications for noninvasive positive pressure ventilation in chronic respiratory failure due to restrictive lung disease, COPD, and nocturnal hypoventilation - a concensus conference report. Chest, 116 (2), 521-534.

Golpe, R., Jiménez, A. \& Carpizo, R. (2002). Home sleep studies in the assessment of sleep apnea/hypopnea syndrome. Chest, 122 (4), 1156-1161.

Guilleminault, C. Philip, C. \& Robinson, A. (1998). Sleep and neuromuscular disease: bilevel positive airway pressure by nasal mask as a treatment for sleep disordered breathing in patients with neuromuscular disease. Neurology, Neurosurgery \& Psychiatry, 65 (2), 225-232.

Hagren, B, Pettersen, I. M., Severinsson, E. Lutzen, K. \& Clyne, N. (2001). The haemodialysis machine as a lifeline: experiences of suffering from end-stage renal disease. Journal of Advanced Nursing, 34 (2), 196-202.

Halldórsdóttir, B., Ingadóttir, T. S. \& Gíslason, T. (2003). Home mechanical ventilation in Iceland 2003. Lungeforum, Scandinavian Respiratory Journal, Supplement 22, vol 13, 75 .

Hammond, J. \& McCann. E. (2003). Duchenne muscular dystrophy a physical education: A case study. Journal of Physical Education New Zealand, 36 (1), 82-92.

Harding, S. M. (2000). Complications and consequences of obstructive sleep apnea. Current Opinion in Pulmonary Medicine, 6 (6), 485-489. 
Heidegger, M. (1977). The question concerning technology and other essays. New York: Garland Publishing.

Hess, J. D. (1996). The ethics of compliance: A dialectic. Advances in Nursing Science, 19 (1), 18-27.

Hess, J. D. (2003). Gadow's relational narrative: an elaboration. Nursing Philosophy, $4,137-148$.

Huffman, C. and Sandelowski, M. (1997). The nurse-technology relationship: the case of ultrasonography. Journal of Obstetric, Gynecologic \& Neonatal Nursing, $26(2), 673-682$.

Hutchinson, S. A., Wilson, M. E. and Wilson, H. S. (1994). Benefits of participating in research interviews. Image - Journal of Nursing Scholarship, 26 (2), 161164.

Johns, M. W. (1991). A new method for mesuring daytime sleepiness: The Ephworth sleepiness scale. Sleep, 14 (6), 540-545.

Jokic, R., Zintel, T., Sridhar, G., Gallagher, C. G. and Fitzpatrick, M. F. (2000). Ventilatory responses to hyercapnia and hypoxia in relatives of patients with the obesity hypoventilation syndrome. Thorax, 55, 940-945.

Jónsdóttir, H. (2001). Specialized nursing intervention for the chonically ill. In H. Sveinsdóttir and A. Nyysti (Eds.) The future of primary nursing care (pp. 135-142), proceedings from a conference held by the Institude of Nursing Research and the Reykjavik Center of Public Health, September 13-14, 2001. Reykjavík: University Press and the Institude of Nursing research.

Karakurt, S., Fanfulla, F. \& Nava, S. (2001). Is it safe for patients with chronic hypercapnic respiratory failure undergoing home noninvasive ventilation to discontinue ventilation briefly. Chest, 119 (5), $1379-1386$.

Kjartansson, G., Ingadóttir, S., Halldórsdóttir, B., Gunnarsdóttir, A., Guðmundsson, G., Einarsson, E.Ö. \& Gíslason, P. (2001). Home mechanical ventilation in Iceland. The Icelandic Medical Journal, 87 (6), 521-525.

Kvale, S. (1996). InterViews. An introduction to qualitative research interviewing. California: Sage Publ. 
Leonard, V. W. (1994). A Heideggerian phenomenological perspective. In P. Benner (Ed.). Interpretive Phenomenology: Embodiment, caring, and ethics in health and illness (pp. 43-63). Thousand Oaks, CA: Sage

Lindahl, B., Sandman, P-O. \& Rasmussen, B. H. (2003). Meanings of living at home on a ventilator. Nursing Inquiry, 10 (1), 19-27.

Locsin, R. C. (1995). Machine technologies and caring in nursing. Image: Journal of Nursing Scholarship, 27 (3), 201-203.

Locsin, R.C. (1998). Tecnologic competence as caring in critical care nursing. Holistic Nursing Practice, 12 (4), 50-56.

Lowry, D. A. (1998). Issues of non-compliance in mental health. Journal of Advanced Nursing, 28 (2), 280-287.

McNicholas, W. T. (2000). Impact of sleep in COPD. Chest, 117 (2), 48S.

Mattingly, C and Garro, L. C. (1994). Introduction. Scocial Science and Medicine, 38 (6), 771-774.

McConnell, E. (1998). The coalescence of technology and humanism in nursing practice: It doesn't just happen and it doesn't come easily. Holistic Nursing Practice, 12, (4), 23-30.

Merriam-Webster's Online Dictionary (2003). Encyclopedia Brittanica, inc. Retrived Oktober 272003 on the World Wide Web: http://search.eb.com/dictionary?book=Dictionary\&va

Mitchell, G. J. (2001). Pictures of paradox: Technology, nursing, and human science. In R. C. Locsin (Ed.) Advancing Technology, Caring and Nursing (22-40). Westport, CT: Auburn House.

Murphy, N. \& Canales, M. (2001). A critical analysis of compliance. Nursing Inquery 8, 173-181.

Nauffal, D., Doménech, R., Martínez García, M.A.,Compte, L., Macián, V. \& Perpiná, M. (2002). Non-invasive positive pressure home ventilation in restrictive disorders: outcome and impact on health-related quality of life. Respiratory Medicine, 96, 777-783. 
Newman, M. (1986). Health as expanding consciousness. St. Louis, Missouri: Mosby.

Nugent, A., Smith, I. E. \& Shneerson, J. M. (2002). Domiciliary-assisted ventilation in patients with myotonic dystrophy. Chest, 121 (2), 459-464.

Pehrson, K., Olofsson, J., Larsson, S. \& Sullivan, M. (1994). Quality of life of patients treated by home mechanical ventilation due to restrictive ventilatory disorder. Respiratory Medicine, 88, 21-26.

Perkins, L. \& Shortall, S. (2000). Ventilation without intubation. RN, 63 (1), 34-39.

Plager, K. A. (1994). Hermeneutic Phenomenology: A methodology for family Health and Health Promotion Study in Nursing. In P. Benner (Ed.). Interpretive Phenomenology: Embodiment, caring, and ethics in health and illness (pp. 65-83). Thousand Oaks, CA: Sage

Polit, D.F. \& Hungler, B.P. (1997). Essentials of nursing research methods, appraisal, and utilization (4th. Ed.). New York: Lippincott.

Polkinghorne, D. E. (1988). Narrative knowing and the human sciences. New York: State University of New York press.

Polkinghorne, D. E. (1995). Narrative configuration in qualitative analysis. In J. A. Hatch and R. Wisniewski (Editors). Life history and narrative (pp. 5-23). London: The Falmer press.

Punjabi, N. M., Sorkin, J. D., Katzel, L. I., Goldberg, A. P., Schwartz, A. R. \& Smith, P. L. (2002). Sleep disordered breathing and insulin resistance in middle-aged and overweight men. American Journal of Respiratory \& Critical Care Medicine, 165 (5), 677-682.

Ragette, R., Mellies, U., Schwake, C., Voit, T. \& Teschler (2002). Patterns and predictors of sleep disordered breathing in primary myopathies. Thorax, 57, 724-728.

Ray, M. A. (1987). Technological caring: A new model in critical care. Applied Research, 6 (3), 166-173.

Rees, P. J. \& Dudley, F. (1998). ABC of oxygen: Oxygen therapy in chronic lung disease. British Medical Journal, 317 (7162), 871-874. 
Riessman, C. K. (2002). Analysis of personal narratives. In J. F. Gubrium and J. A. Holstein (Eds.) Handbook of interview research, context and method. London: Thousand Oaks.

van der Riet, P. (1997). The body, the person, technologies in nursing. In J. Lawler (Ed.), The body in nursing (pp. 95-107). South Melbourne: Churchill Livingstone.

Ring, L. \& Danielson, E. (1997). Patients' experience of long-term oxygen therapy. Journal of Advanced Nursing, 26 (2), 337-344.

Russel, S, Daly, J., Hughes, E. \& op't Hoog, C. (2003). Nurses and "difficult" patients: negotiating non-compliance. Journal of Advanced Nursing, 43 (3), 281-287.

Sandelowski, M. (1993). Toward a theory of technology dependency. Nursing Outlook, 41 (1), 36-42.

Sandelowski, M. (1994). We are the stories we tell, narrative knowing in nursing practice. Journal of Holistic Nursing, 12 (1), 23-33.

Sandelowski, M. (1995). Sample size in qualitative research. Research in Nursing and Health, 18, 170-183.

Sandelowski, M. (1997). (Ir) reconcilable differences? The debate concerning nursing and technology. Image: Journal of Nursing Scholarship, 29 (2), 169-174.

Sandelowski, M. (2002). Visible humans, vanishing bodies, and virtual nursing: complications of life, presence, place and identidy. Advances in Nursing Science, 24 (3), 58-70.

Schoenhofer, S. O. (2001 a). A framework for caring in a technologically dependent nursing environment. In R. C. Locsin (Ed.) Advancing technology, caring and nursing (pp. 3-11). Westport, CT: Auburn House.

Schoenhofer, S. O. (2001 b). Outcomes of caring in high-technology practice environments. In R. C. Locsin (Ed.) Advancing technology, caring and nursing (pp. 79-87). Westport, CT: Auburn House.

Sigríður Halldórsdóttir (1997). Implication of the caring/competence dichotomy. In S. Thorne and V. E. Hayes (Eds.), Nursing Praxis, Knowledge and Action (pp. 105-124). New Delhi: Sage Publication. 
Sin, D. D., Logan, A. G., Fitzgerald, F. S., Liu, P. P. \& Bradley, T. D. (2000). Effects of continuous positive airway pressure on cardiovascular outcomes in heart failure patients with and without Cheyne-Stokes respiration. Circulation, 102 (1), 61-66.

Skelton, J. (1996). Caring for patients with motor neuron disease. Nursing Standard, 10 (32), p. 33-36.

Smith, C. E. (1996). Quality of life and caregiving in technological home care. Chapter 5. In J. J. Fitzpatrick and J. Norbeck (Eds.) Annual Review of Nursing Reseaech, 14 (pp. 95-118). New York: Springer Publishing Co.

Smith, C. E., Giefer, C. K. \& Bieker, L. (1991). Technological dependency: a preliminary model and pilot of home total parenteral nutrition. Journal of Community Health Nursing, 8 (4), 245-254.

Smith, B. A. (1999). Ethical and methodological benefits, of using a reflexive journal, in hermeneutic-phenomenological research. Image: Journal of Nursing Scholarship, 31 (4), 359-363.

Somers, V. K. (2002). Sleep and the failing heart. ACCP Sleep Medicine, 107-110.

Sugerman, H. J., Fairman, R. P., Sood, R. K., Engle, K., Wolfe, L. \& Kellum, J. M. (1992). Long-term effects of gastric surgery for treating respiratory insufficiency of obesity. American Journal of Clinical Nutrition, 55, 597S$601 \mathrm{~S}$.

Thomas, P. S. Owen, E. R. T. C., Hulands, G. \& Milledge, J. S. (1989). Respiratory function in the morbidly obese before and after weight loss. Thorax, 44, 382386.

Thorne, S., Kirkham, S. R. \& MacDonald-Emes (1997). Interpretive describtion: A noncategorical qualitative alternative for developing nursing knowledge. Research in Nursing and Health, 20, 169-177.

Tkáćová, R., Štubňa, J. \& Tomori, Z. (2002). Cardiovascular implications of sleep apnea in patients with congestive heart failure. Sborník Lékařský, 103 (1), 7377. 
Young, J., Marshall, C. L. \& Anderson, E. J. (1994). Amylotrophic lateral sclerosis patients' perspectives on use of mechanical ventilation. Health and Social work, 19 (4), 253-260.

Usher, K. \& Holmes, C. (1997). Ethical aspects of phenomenological research with mentally ill people. Nursing Ethics, 4 (1), 49-56.

Wietzenblum, E. (1996). Observance of long-term oxygen theraphy at home. Chest, $109(5), 1135-1136$. 


\section{Attachment 1}

\section{LANDSPITALI}

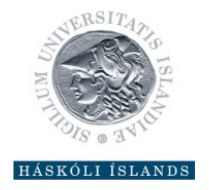

\section{Upplýsingablað um vísindarannsóknina}

Að vera háður tækni til öndunaraðstoðar í svefni: Reynsla sjúklinga og fjölskyldna peirra.

Kæri viðtakandi

Ég undirrituð er hjúkrunarfræðingur, starfandi á Landspítala Háskólasjúkrahúsi Fossvogi og stunda meistaranám við Hjúkrunarfræðideild Háskóla Íslands. Í samstarfi við Helgu Jónsdóttur dósent við hjúkrunarfræðideild Háskóla Íslands hef ég ákveðið að gera rannsókn á reynslu einstaklinga sem nota tæknilega öndunaraðstoð í svefni og maka peirra eða öðrum úr fjölskyldu. Með bréfi pessu leita ég eftir pátttöku pinni og maka píns eða annars fjölskyldumeðlims, í pessari rannsókn og mun hér á eftir úrskýra nánar hvað felst í pví.

Pátttakendur eru valdir úr hópi einstaklinga sem eru skráđir notendur heimaöndunarvéla á svefnrannsóknareiningu lungnadeildar A-6 LSH Fossvogi. Rannsókn pessi er í formi viðtala við einstaklinga og maka eða fjölskyldumeðlims um pá reynslu að nota tækjabúnað til að halda lífi og heilsu og eru útskrifaðir heim af sjúkrahúsi. 
Sampykki á páttöku felst í pví að ég tek við ykkur 2 viðtöl saman. Viðtölin verða u.p.b. einnar klukkustundar löng og verða tekin með nokkurra vikna millibili. Staðsetning viðtalanna verður par sem pið kjósið helst, eigið heimili, sjúkrastofnun eða á Rannsóknarstofnun í hjúkrunarfræði. Viðtölin snúast um sameiginlega reynslu ykkar beggja af bví að nota tækjabúnað til að viðhalda lífi og heilsu. Viðtölin verða tekin upp á segulband. Heitið er nafnleynd og ekki verður hægt að rekja upplýsingar til ykkar. Gögnin verða í minni vörslu og geymd par til að lokinni úrvinnslu. Gögnum verður eytt að úrvinnslu lokinni. Niðurstöður pessarar rannsóknar verða birtar í meistararitgerð minni sem mun liggja frammi á pjóðarbókhlöðu. Tímaritsgreinar verða einnig birtar í erlendu og innlendu ritrýndu tímariti.

Pátttaka í rannsókninni hefur í för með sér hverfandi áhættu, en ópægindi gætu verið fólgin í pví að vera spurð/spurður um málefni sem geta reynst ykkur erfitt að horfast í augu við. Ykkur er alfarið í sjálfsvald sett hvort pið svarið öllum spurningum sem lagðar eru fyrir ykkur.

Ef pú er viljug (ur) að taka pátt í pessari rannsókn bið ég pig að ræða pað við maka pinn eða nánasta aðstandanda. Alda Gunnarsdóttir deildarstjóri á deild A-6 mun síðan ræða við pig og leita eftir sampykki ykkar fyrir pví að ég hafi samband við ykkur og kynni frekar rannsókn.

Pátttaka ykkar í rannsókninni getur varpað ljósi á reynslu einstaklinga og fjölskyldna af pví að nota tæknilegan búnað til meðhöndlunar á svefnháðum öndunartruflunum til pess að viðhalda lífi og heilsu. Slík vitneskja getur stuðlað að bættri hjúkrun og stuðningi við einstaklinga í slíkum aðstæðum.

Dið hafið rétt til að hafna pátttöku í rannsókninni og getið einnig hætt pátttöku hvenær sem er eftir að hún er hafin. Höfnun á páttöku í rannsókninni hefur á engan hátt áhrif á pá heilbrigðispjónustu sem pið komið til með að purfa á að halda á LSH í framtíðinnni.

Rannsóknin hefur hlotið samykki Siðanefndar Landspítala Háskólasjúkrahúss og tilkynnt hefur verið til Persónuverndar um framkvæmd hennar. Niðurstöður 
rannsóknarinnar verða kynntar í innlendu og erlendu tímariti og á ráðstefnum fagaðila. Helga Jónsdóttir er ábyrgðarmaður pessarar vísindarannsóknar.

Pað er enginn kostnaður af ykkar hálfu vegna páttöku í rannsókninni.

Kærar pakkir

Rannsakandi:

Leiðbeinandi:

Porbjörg Sóley Ingadóttir

Dr. Helga Jónsdóttir, dósent

Hs: 5652274 Vs: 5436673,5436033

Sími: 5254990

torbjsol@landspitali.is

helgaj@hi.is 


\section{Attachment 2}
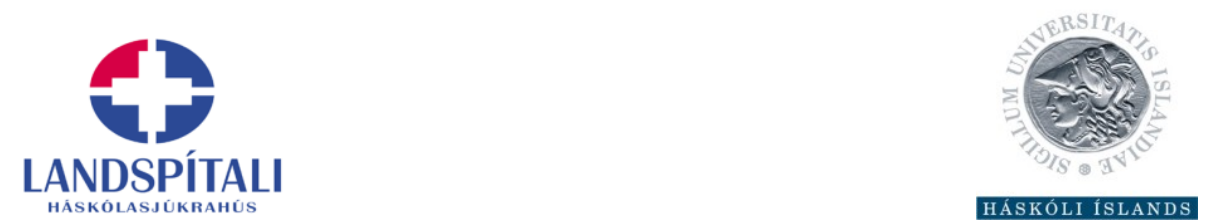

\section{Upplýst sampykki fyrir pátttöku í vísindarannsókninni}

Að vera háður öndunaraðstoð í svefni: Reynsla sjúklinga og fjölskyldna peirra.

Við undirrituð höfum verið beðin um að taka pátt í rannsókn sem Porbjörg Sóley Ingadóttir hjúkrunarfræðingur er að vinna að um reynslu sjúklinga sem parfnast öndunaraðstoðar í svefni og reynslu maka eða annars fjölskyldumeðlims. Okkur er boðin pátttaka í rannsókn pessari, par sem við höfum pessa reynslu.

Ef við sampykkjum að taka pátt í rannsókn pessari mun eftirfarandi eiga sér stað: Tekin verða við okkur tvö viðtöl sem að okkar vali fara fram á heimili mínu, í húsnæði Rannsóknarstofnunar í hjúkrunarfræði eða á Landspítala háskólasjúkrahúsi (LSH), af rannsakandanum Porbjörgu Sóleyju Ingadóttur. Við munum verða beðin um að segja frá reynslu okkar varðandi öndunaraðstoð í svefni. Hvort viðtal mun taka u.p.b. klukkustund. Vðtölin verða tekin upp á segulband, vélrituð og að lokinni rannsókn verður gögnum eytt. Meðan á rannsókn stendur verða gögn í öruggri vörslu rannsakanda.

Rannsókn pessi mun einungis hafa í för með sér hverfandi áhættu fyrir okkur. Með frásögn okkar verður farið með sem trúnarðarmál. Рað er frjálst val að taka pátt í 
pessari rannsókn og ákvörðun mín um pátttöku mun ekki á nokkurn hátt hafa áhrif á pjónustu LSH við okkur.

Farið verður með niðurstöður rannsóknarinnar sem trúnaðarmál og verða rannsóknargögn án persónuauðkenna. Eingöngu rannsóknaraðilar hafa aðgang að pessum gögnum. Í greinum og skýrslum sem birtast um niðurstöður rannsóknarinnar mun ekki vera hægt að greina svör sem okkar. Að lokinni rannsókn mun öllum gögnum verða eytt.

Рað mun ekki vera neinn beinn ávinningur fyrir okkur að taka pátt í pessari rannsókn, fremur megi horfa á pað sem hugsanlegan ávinning fyrir fólk sem parfnast tæknilegrar meðferðar með öndunaraðstoð í svefni.

Okkur er frjálst að neita að svara einstökum spurningum. Einnig er okkur frjálst að neita pví að taka pátt í pessari rannsókn eða að hætta við hvenær sem er án pess að pað hafi á nokkurn hátt áhrif á heilbrigðispjónustu við okkur í framtíðinni. Pátttaka í rannsókninni hefur ekki neinn kostnað í för með sér fyrir okkur, né munum við fá bætur fyrir pátttöku okkar í henni.

Rannsókn pessi hefur hlotið sampykki Siðanefndar Landspítala - háskólasjúkrahúss og verið tilkynnt til Persónuvernar.

Rannsóknin hefur verið útskýrð fyrir mér af Đorbjörgu Sóleyju Ingadóttur og Öldu Gunnarsdóttur deildarstjóra lungnadeildar A-6 í Fossvogi. Ef ég hef frekari spurningar um rannsókn pessa, get ég haft samband við Porbjörgu Sóleyju í síma 543-6673 / 5436033 og 696-9976, netfang: torbjsol@landspitali.is við Öldu í síma 543-6670 og Helgu Jónsdóttur dósent við hjúkrunarfræðideild Háskóla Íslands sem er ábyrgðarmaður rannsóknarinnar í síma 525-4990 og 551-7668, netfang: helgaj@hi.is 
„Upplýsingablað” og „Upplýst sampykki” eru í tvíriti og munum við halda eftir eintaki af hvorutveggja. Pátttaka í rannsókn er af fúsum og frjálsum vilja pátttakenda. Okkur er frjálst að hafna pátttöku eða draga okkur út úr henni hvenær sem við viljum. Ákvörðun okkar mun ekki á neinn hátt hafa áhrif á pjónustu LSH við okkur í framtíðinni.

Mér hefur verið kynnt eðli og umfang pessarar vísindarannsóknar og ég er sampykk (ur) pátttöku.

Dagsetning

Nafn pátttakanda

Nafn pátttakanda úr fjölskyldu

Nafn rannsakanda 


\title{
Attachment 3
}

\section{Viðtalsrammi (interview structure)}

\author{
Að nota toekin
}

Getur pú sagt mér frá peirri reynslu að nota pennan tækjabúnað.

Getur pú sagt mér frá aðdraganda meðferðarinnar - ákvarðanatöku - hafðir pú möguleika á að taka pátt í peirri ákvörðun að hefja pessa meðferð?

Hvernig var pað að byrja að nota pessi tæki (Hverju breytti pað? Var pað erfitt? Hvað kom á óvart? Hvað tók lengstan tíma að glíma við?

Hvernig sjáið pið fyrir ykkur framtíðina varðandi sjúkdóm og notkun pessara tækja?

Hvernig tók fjölskyldan pessari meðferð?

Hvernig er að nota tækin daglega dags? Hefur hún breytt einhverju í daglegu lífi ykkar?

Getur pú lýst fyrir mér peim áhrifum sem pessi meðferð hefur haft á pig.

Hefur tilvist tækjanna áhrif á samband ykkar hjóna?

\section{Samskipti við heilbrigðisstarfsmenn}

Hvernig voru pér kynnt tækin (Möguleikar til að meðhöndla sjúkdóm, möguleg vandamál vegna tækjanna).

Getið pið sagt mér frá pví hvernig pið upplifið samskipti við starfsfólk (hjúkruarfræðinga / lækna / sjúkraliða).

Getið pið lýst peirri aðstoð sem pið mynduð óska eftir frá heilbrigðisstarfsfólki. 
Hvaða ráð gætir pú gefið öðrum sem purfa á slíkri meðferð að halda.

Er eitthvað sem pið gætuð ráðlagt heilbrigðisstarfsfólki að mætti betur fara í undirbúningi og stuðningi við sjúklinga og aðstandendur peirra sem parfnast langvarandi tæknilegrar meðferðar sem pessarar. 